\title{
Total Dissolved Gas and Water Temperature in the Lower Columbia River, Oregon and Washington, Water Year 2010: Quality-Assurance Data and Comparison to Water-Quality Standards
}

By Dwight Q. Tanner, Heather M. Bragg, and Matthew W. Johnston

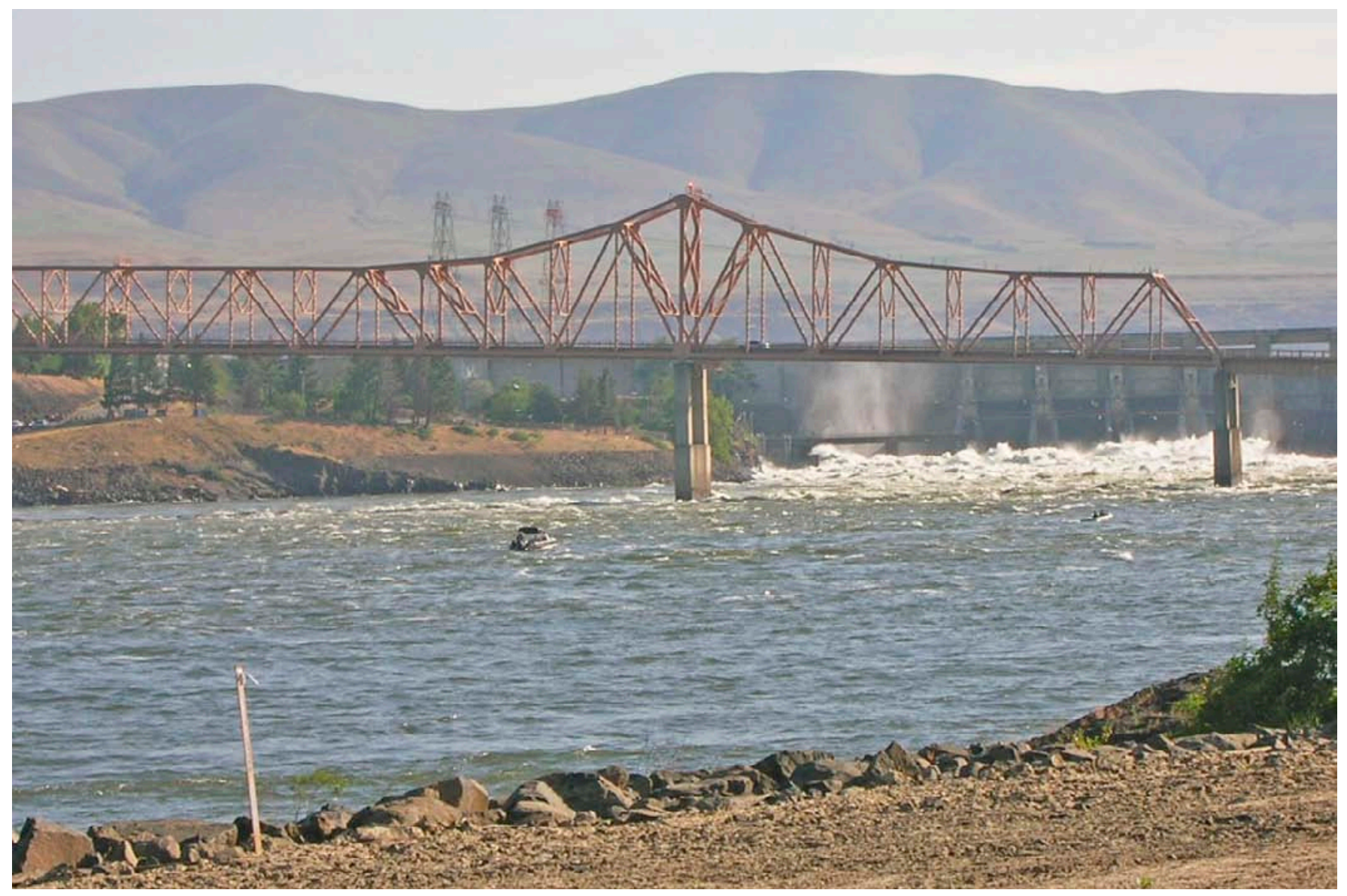

Prepared in cooperation with the U.S. Army Corps of Engineers

Open-File Report 2010-1293

U.S. Department of the Interior

U.S. Geological Survey 
Cover: The Dalles Dam on the Columbia River (behind bridge). Spill from the dam aerates water in the river, causing an increase in dissolved-gas concentrations. (Photograph by Dwight Tanner, USGS.) 


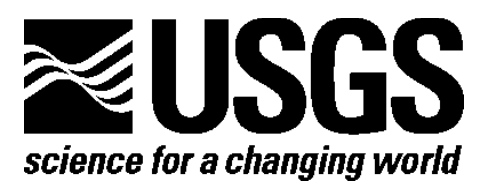

Prepared in cooperation with the U.S. Army Corps of Engineers

\section{Total Dissolved Gas and Water Temperature in the Lower Columbia River, Oregon and Washington, Water Year 2010: Quality-Assurance Data and Comparison to Water-Quality Standards}

By Dwight Q. Tanner, Heather M. Bragg, and Matthew W. Johnston

Open-File Report 2010-1293

U.S. Department of the Interior U.S. Geological Survey 


\title{
U.S. Department of the Interior \\ KEN SALAZAR, Secretary
}

\author{
U.S. Geological Survey \\ Marcia K. McNutt, Director
}

U.S. Geological Survey, Reston, Virginia: 2011 For more information on the USGS_the Federal source for science about the Earth, its
natural and living resources, natural hazards, and the environment, visit http://www.usgs.gov
or call 1-888-ASK-USGS.
For an overview of USGS information products, including maps, imagery, and publications,
visit http://www.usgs.gov/pubprod

To order this and other USGS information products, visit $h$ ttp://store.usgs.gov

\begin{abstract}
Suggested citation:
Tanner, D.Q., Bragg, H.M., and Johnston, M.W., 2011, Total dissolved gas and water temperature in the lower Columbia River, Oregon and Washington, water year 2010: Quality-assurance data and comparison to water-quality standards: U.S. Geological Survey Open-File Report 2010-1293, 28 p.
\end{abstract}

The use of trade, product, or firm names is for descriptive purposes only and does not imply endorsement by the U.S. Government.

Although this report is in the public domain, permission must be secured from the individual copyright owners to reproduce any copyrighted material contained within this report. 


\section{Contents}

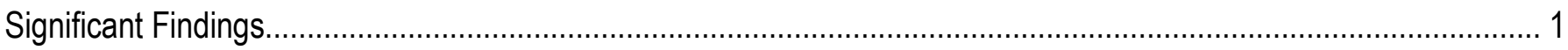

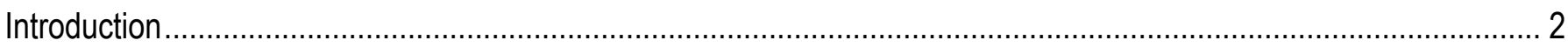

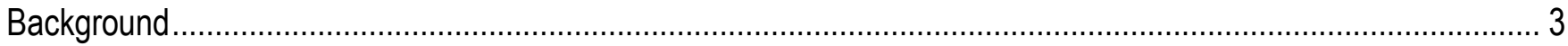

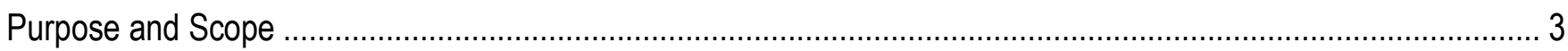

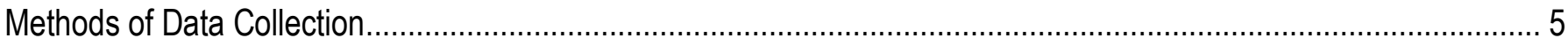

Summary of Total-Dissolved-Gas Data Completeness and Quality .............................................................. 5

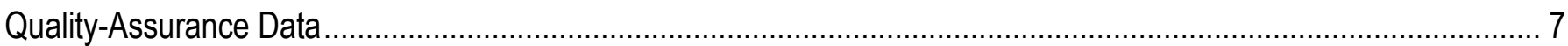

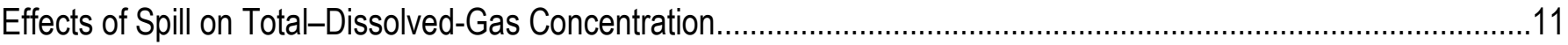

Comparison of Total-Dissolved-Gas Concentration and Temperature to Standards ..............................................13

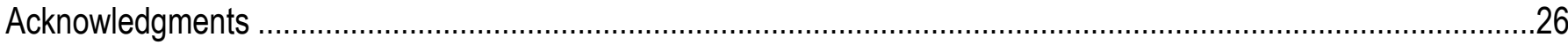

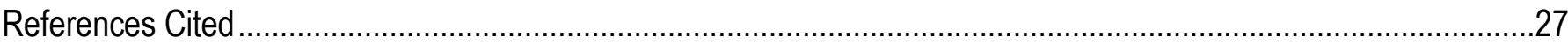

\section{Figures}

Figure 1. Location of total-dissolved-gas monitoring stations, lower Columbia River, Oregon and Washington, water year 2010.

Figure 2. Boxplot showing accuracy of total-dissolved-gas sensors in the laboratory after 3 or 4 weeks of field deployment at eight monitoring stations in the lower Columbia River, Oregon and Washington, water year 2010 (number of comparison values $=105$ ).

Figure 3. Boxplot showing difference between the secondary standard and the field barometers in the field after 3 or 4 weeks of field deployment at eight stations in the lower Columbia River, Oregon and Washington, water year 2010.

Figure 4. Boxplot showing difference between the secondary standard and the field temperature instruments in the field after 3 or 4 weeks of field deployment at eight stations in the lower Columbia River, Oregon and Washington, water year 2010.

Figure 5. Boxplot showing difference between the secondary standard and the field total-dissolved-gas instruments in the field after 3 or 4 weeks of field deployment at eight stations in the lower Columbia River, Oregon and Washington, water year 2010.

Figure 6. Graph showing relation of total-dissolved-gas saturation downstream of John Day Dam and spill from John Day Dam, lower Columbia River, Oregon and Washington, April 1-August 31, 2010.

Figure 7. Graph showing relation of total-dissolved-gas saturation downstream of The Dalles Dam and spill from The

Dalles Dam, lower Columbia River, Oregon and Washington, April 1-August 31, 2010.

Figure 8. Graph showing relation of total-dissolved-gas saturation downstream of Bonneville Dam at Cascade Island and spill from Bonneville Dam, lower Columbia River, Oregon and Washington, April 1-August 31, 2010.

Figure 9. Graph showing relation of total-dissolved-gas saturation downstream of Bonneville Dam at Warrendale and spill from Bonneville Dam, lower Columbia River, Oregon and Washington, April 1-August 31, 2010.

Figure 10. Boxplot showing distributions of hourly total-dissolved-gas data and Oregon and Washington water-quality

variances, lower Columbia River, Oregon and Washington, April 1-August 31, 2010.....

Figure 11. Graphs showing total-dissolved-gas saturation at John Day Dam navigation lock and spill from McNary Dam (76 river miles upstream from John Day Dam), lower Columbia River, Oregon and Washington, April 1-August 31,2010 
Figure 12. Graphs showing total-dissolved-gas saturation at John Day Dam tailwater and spill from John Day Dam, lower Columbia River, Oregon and Washington, April 1-August 31, 2010.

Figure 13. Graphs showing total-dissolved-gas saturation at The Dalles Dam forebay and spill from John Day Dam, lower Columbia River, Oregon and Washington, April 1-August 31, 2010.

Figure 14. Graphs showing total-dissolved-gas saturation at The Dalles Dam tailwater and spill from The Dalles Dam, lower Columbia River, Oregon and Washington, April 1-August 31, 2010.

Figure 15. Graphs showing total-dissolved-gas saturation at Bonneville Dam forebay and spill from The Dalles Dam, lower Columbia River, Oregon and Washington, April 1-August 31, 2010

Figure 16. Graphs showing total-dissolved-gas saturation at Cascade Island and spill from Bonneville Dam, lower Columbia River, Oregon and Washington, April 1-August 31, 2010

Figure 17. Graphs showing total-dissolved-gas saturation at Warrendale and spill from Bonneville Dam, lower Columbia River, Oregon and Washington, April 1-August 31, 2010

Figure 18. Graphs showing total-dissolved-gas saturation at Camas and spill from Bonneville Dam, lower Columbia River, Oregon and Washington, April 1-August 31, 2010

Figure 19. Graph showing water temperature upstream of John Day Dam and downstream of John Day Dam, lower Columbia River, Oregon and Washington, summer 2010

Figure 20. Graph showing water temperature upstream and downstream of The Dalles Dam, lower Columbia River, Oregon and Washington, summer 2010.

Figure 21. Graph showing water temperature upstream of Bonneville Dam and downstream of Bonneville Dam at Cascade Island, lower Columbia River, Oregon and Washington, summer 2010

Figure 22. Graph showing water temperature upstream of Bonneville Dam and downstream of Bonneville Dam at Warrendale, lower Columbia River, Oregon and Washington, summer 2010.

Figure 23. Graph showing water temperature downstream of Bonneville Dam at Camas, lower Columbia River, Oregon and Washington, summer 2010.

\section{Tables}

Table 1. Total-dissolved-gas monitoring stations, lower Columbia River, Oregon and Washington, water year 2010

Table 2. Total-dissolved-gas data completeness and quality, lower Columbia River, Oregon and Washington, water year 2010

Table 3. Major portions of missing or deleted data, lower Columbia River, Oregon and Washington, water year 2010 


\section{Conversion Factors, Datum, Abbreviations, and Acronyms}

\section{Conversion Factors}

\begin{tabular}{lll}
\hline \multicolumn{1}{c}{ Multiply } & \multicolumn{1}{c}{ By } & \multicolumn{1}{c}{ To obtain } \\
\hline cubic foot per second $\left(\mathrm{ft}^{3} / \mathrm{s}\right)$ & 0.02832 & cubic meter per second $\left(\mathrm{m}^{3} / \mathrm{s}\right)$ \\
mile (mi) & 1.609 & kilometer $(\mathrm{km})$ \\
millimeter (mm) & 0.03937 & inch (in.) \\
square mile $\left(\mathrm{mi}^{2}\right)$ & 2.590 & square kilometer $\left(\mathrm{km}^{2}\right)$ \\
\hline
\end{tabular}

Temperature in degrees Celsius $\left({ }^{\circ} \mathrm{C}\right)$ may be converted to degrees Fahrenheit $\left({ }^{\circ} \mathrm{F}\right)$ as follows: ${ }^{\circ} \mathrm{F}=\left(1.8 x^{\circ} \mathrm{C}\right)+32$.

\section{Datum}

Horizontal coordinate information is referenced to the North American Datum of 1927 (NAD 27).

$\begin{array}{ll}\text { Abbreviations and Acronyms } \\ \text { BON } & \text { Bonneville forebay } \\ \text { COW } & \text { Cascade Island } \\ \text { CWMW } & \text { Camas } \\ \text { DCP } & \text { Data-collection platform } \\ \text { GOES } & \text { Geostationary Operational Environmental Satellite } \\ \text { JDY } & \text { John Day navigation lock } \\ \text { JHAW } & \text { John Day Dam tailwater } \\ \text { NIST } & \text { National Institute of Standards and Technology } \\ \text { RM } & \text { River mile } \\ \text { TDA } & \text { The Dalles forebay } \\ \text { TDDO } & \text { The Dalles tailwater } \\ \text { TDG } & \text { Total dissolved gas } \\ \text { USACE } & \text { U.S. Army Corps of Engineers } \\ \text { USGS } & \text { U.S. Geological Survey } \\ \text { WRNO } & \text { Warrendale } \\ \text { WT } & \text { Water temperature }\end{array}$


This page is intentionally blank 


\title{
Total Dissolved Gas and Water Temperature in the Lower Columbia River, Oregon and Washington, Water Year 2010: Quality-Assurance Data and Comparison to Water- Quality Standards
}

\author{
By Dwight Q. Tanner, Heather M. Bragg, and Matthew W. Johnston
}

\section{Significant Findings}

When water is released through the spillways of dams, air is entrained in the water, increasing the downstream concentration of dissolved gases. Excess dissolved-gas concentrations can have adverse effects on freshwater aquatic life. The U.S. Geological Survey (USGS), in cooperation with the U.S. Army Corps of Engineers, collected dissolved-gas and water-temperature data at eight monitoring stations on the lower Columbia River in Oregon and Washington in 2010. Significant findings from the data include:

- $\quad$ During the spill season of April through August 2010, hourly values of total dissolved gas (TDG) were occasionally larger than 115-percent saturation for the forebay stations (John Day navigation lock, The Dalles forebay, Bonneville forebay, and Camas). Hourly values of total dissolved gas were occasionally larger than 120-percent saturation for four tailwater stations (John Day Dam tailwater, The Dalles tailwater, Cascade Island, and Warrendale).

- From late July to late August or early September 2010, hourly water temperatures were greater than $20^{\circ} \mathrm{C}$ (degrees Celsius) at the eight stations on the lower Columbia River. According to the State of Oregon temperature standard, the 7-day average maximum temperature of the lower Columbia River should not exceed $20^{\circ} \mathrm{C}$; Washington regulations state that the 1-day maximum should not exceed $20^{\circ} \mathrm{C}$ as a result of human activities.

- All 105 laboratory checks of the TDG sensors (without the membrane attached) with a certified pressure gage were within \pm (plus or minus) 0.5 percent saturation after 3 to 4 weeks of deployment in the river.

- All but 1 of the 85 in situ field checks of TDG sensors with a secondary standard were within \pm 2.0 percent saturation after 3-4 weeks of deployment in the river. All 88 of the field checks of barometric pressure were within \pm 1 millimeter of mercury of a primary standard, and all 87 watertemperature field checks were within $\pm 0.2^{\circ} \mathrm{C}$ of a secondary standard.

- For the eight monitoring stations in water year 2010, a total of 99.7 percent of the TDG data were received in real time and were within 1-percent saturation of the expected value on the basis of calibration data, replicate quality-control measurements in the river, and comparison to ambient river conditions at adjacent stations. Data received from the individual stations ranged from 98.4 to 100.0 percent complete. 


\section{Introduction}

The U.S. Army Corps of Engineers (USACE) operates several dams in the lower Columbia River Basin in Oregon and Washington (fig. 1), which encompasses 259,000 $\mathrm{mi}^{2}$ of the Pacific Northwest. These dams are multipurpose structures that fill regional needs for flood control, navigation, irrigation, recreation, hydropower production, fish and wildlife habitat, water-quality maintenance, and municipal and industrial water supply. When water is released through the spillways of these dams (instead of being routed through the turbines to generate electricity), ambient air is entrained in the water, increasing the concentration of dissolved gases (known as the "total dissolved gas" concentration [TDG]) downstream of the spillways. TDG conditions greater than 110-percent saturation can cause gas-bubble trauma in fish and adversely affect other aquatic organisms (U.S. Environmental Protection Agency, 1986).

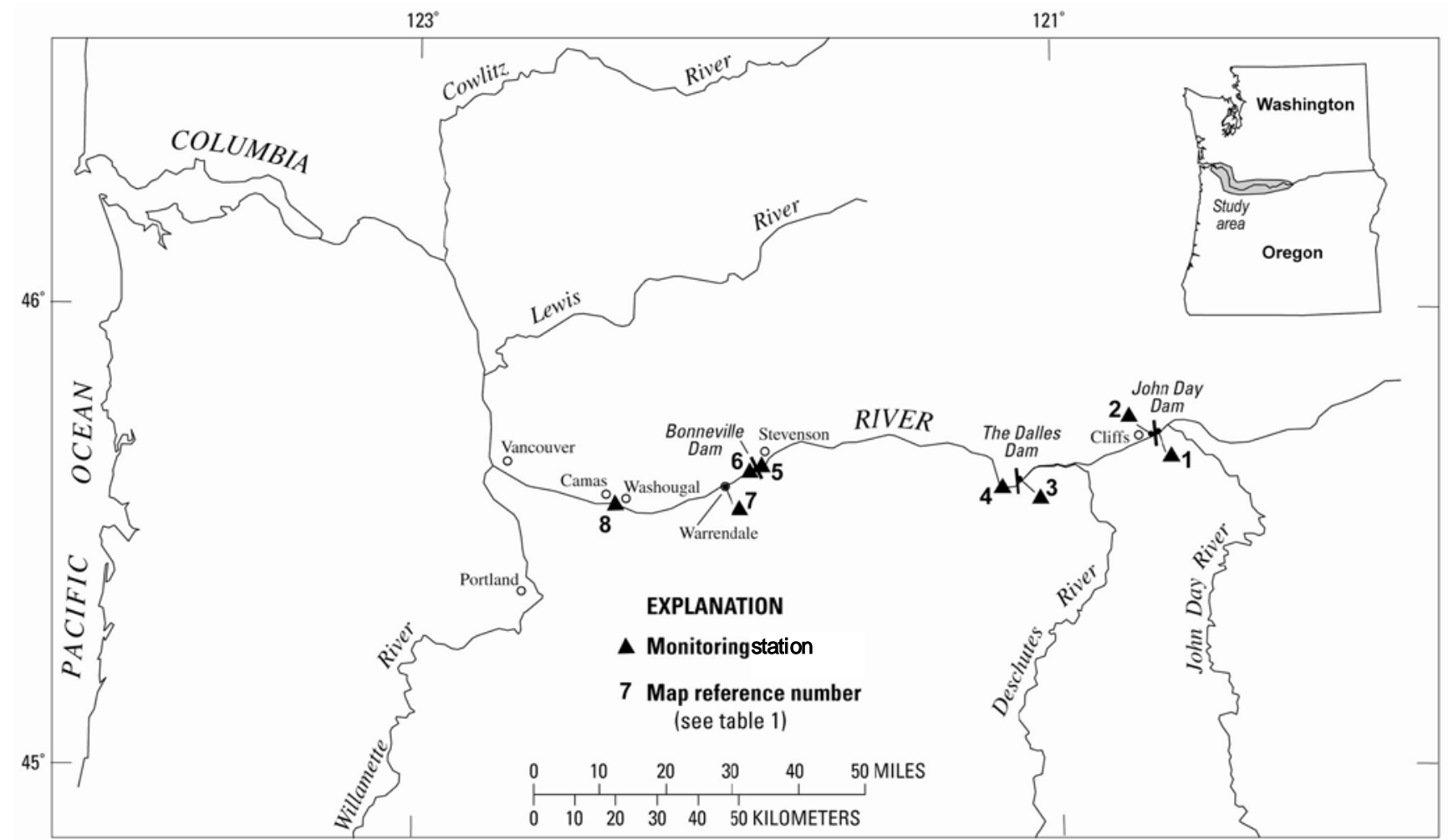

Basemap modified from USGS and other digital data, variable scales. Projection unknown.

Figure 1. Location of total-dissolved-gas monitoring stations, lower Columbia River, Oregon and Washington, water year 2010.

The USACE regulates spill and streamflow to minimize the production of excess TDG downstream from its dams, but also with the goal of providing for fish passage with spilled water (rather than passage through the turbines). Consequently, the States of Oregon and Washington issue variances to the TDG water-quality standards during the spring and summer. To monitor compliance with these variances, the USACE oversees the collection of real-time TDG and water-temperature data upstream and downstream of Columbia River Basin dams in a network of monitoring stations. Data from the lower Columbia River monitoring stations are available within about 1 hour of current time. 


\section{Background}

Real-time TDG and water-temperature data are vital to the USACE for dam operation and for monitoring compliance with environmental regulations. The data are used by water managers to maintain water-quality conditions that facilitate fish passage and survival in the lower Columbia River. The U.S. Geological Survey (USGS), in cooperation with the Portland District of the USACE, has collected TDG and related data in the lower Columbia River each year since 1996. Current and historical TDG and water-temperature data can be accessed at http://oregon.usgs.gov/projs_dir/pn307.tdg/ (accessed October 25, 2010). Eleven reports, published for water years 1996 and 2000-2009, contain TDG data, quality-assurance data, and descriptions of the methods of data collection (Tanner and others, 1996; Tanner and Bragg, 2001; Tanner and Johnston, 2001, Tanner and others, 2002, 2003, 2004, 2005, 2006, 2007, 2008, 2009).

To assure the quality of the data used for managing and modeling TDG in the lower Columbia River, hourly values for 2010 were reviewed relative to laboratory and field measurements made during instrument calibrations and daily intersite comparisons. A small fraction of the TDG data was deleted because the data did not meet a \pm 1 -percent criterion during quality control checks. The hourly values were stored in a USGS database and in a USACE database (http://www.nwdwc.usace.army.mil/tmt/wcd/tdg/months.html, accessed October 25, 2010). The USACE database also includes hourly water temperature, discharge, and spill data.

\section{Purpose and Scope}

TDG monitoring in the lower Columbia River provides the USACE with (1) real-time data for managing streamflow and spill at its project dams, (2) reviewed TDG data to evaluate conditions relative to water-quality standards, and (3) data for modeling the effect of various management scenarios of streamflow and spill on TDG concentrations.

This report describes the TDG data and related quality-assurance data from eight monitoring stations on the lower Columbia River, from the navigation lock of the John Day Dam (river mile [RM] 215.7) to Camas, Washington (RM 121.7) (fig. 1, table 1). Data for water year 2010 (October 1, 2009, to September 30, 2010) include hourly measurements of TDG pressure, barometric pressure, water temperature, and probe depth. Five of the stations (John Day Dam navigation lock, The Dalles Dam forebay, Bonneville Dam forebay, Cascade Island, and Camas) were operated from February or March to September 2010, the period that includes the usual time of spill from the dams. John Day Dam tailwater and The Dalles Dam tailwater and Warrendale were operated year-round. 
Table 1. Total-dissolved-gas monitoring stations, lower Columbia River, Oregon and Washington, water year 2010

[Map reference number refers to figure 1; USACE, U.S. Army Corps of Engineers; Columbia River mile locations were determined from U.S. Geological Survey (USGS) 7.5-minute topographic maps; stations in this report are referenced by their abbreviated name or USACE station identifier; ', degree; ', minute; ", second; latitude and longitude are referenced to the North American Datum of 1927.]

\begin{tabular}{|c|c|c|c|c|c|c|c|}
\hline $\begin{array}{c}\text { Map } \\
\text { reference } \\
\text { number }\end{array}$ & $\begin{array}{l}\text { USACE } \\
\text { station } \\
\text { identifier }\end{array}$ & $\begin{array}{c}\text { River } \\
\text { mile }\end{array}$ & $\begin{array}{l}\text { USGS } \\
\text { station number }\end{array}$ & $\begin{array}{l}\text { USGS station name } \\
\text { (and abbreviated station name) }\end{array}$ & Latitude & Longitude & $\begin{array}{l}\text { Period of } \\
\text { record in wate } \\
\text { year } 2010\end{array}$ \\
\hline 1 & JDY & 215.7 & 454314120413701 & $\begin{array}{l}\text { Columbia River at John Day navigation lock, } \\
\text { Washington (John Day navigation lock) }\end{array}$ & $45^{\circ} 43^{\prime} 14^{\prime \prime}$ & $120^{\circ} 41^{\prime} 37^{\prime \prime}$ & $\begin{array}{l}03 / 15 / 10- \\
09 / 27 / 10\end{array}$ \\
\hline 2 & JHAW & 214.7 & 454249120423500 & $\begin{array}{l}\text { Columbia River, right bank, near Cliffs, } \\
\text { Washington (John Day tailwater) }\end{array}$ & $45^{\circ} 42^{\prime} 49^{\prime \prime}$ & $120^{\circ} 42^{\prime} 35^{\prime \prime}$ & Year-round \\
\hline 3 & TDA & 192.6 & 453712121071200 & $\begin{array}{l}\text { Columbia River at The Dalles Dam forebay, } \\
\text { Washington (The Dalles forebay) }\end{array}$ & $45^{\circ} 37^{\prime} 12^{\prime \prime}$ & $121^{\circ} 07^{\prime} 12^{\prime \prime}$ & $\begin{array}{l}03 / 12 / 10 \\
09 / / 28 / 10\end{array}$ \\
\hline 4 & TDDO & 188.9 & 14105700 & $\begin{array}{l}\text { Columbia River at The Dalles, Oregon (The } \\
\text { Dalles tailwater) }\end{array}$ & $45^{\circ} 36^{\prime} 27^{\prime \prime}$ & $121^{\circ} 10^{\prime} 20^{\prime \prime}$ & Year-round \\
\hline 5 & BON & 146.1 & 453845121562000 & $\begin{array}{l}\text { Columbia River at Bonneville Dam forebay, } \\
\text { Washington (Bonneville forebay) }\end{array}$ & $45^{\circ} 38^{\prime} 45^{\prime \prime}$ & $121^{\circ} 56^{\prime} 20^{\prime \prime}$ & $\begin{array}{l}03 / 17 / 10- \\
09 / 21 / 10\end{array}$ \\
\hline 6 & CCIW & 145.9 & 453845121564001 & $\begin{array}{l}\text { Columbia River at Cascade Island, Washing- } \\
\text { ton (Cascade Island) }\end{array}$ & $45^{\circ} 38^{\prime} 45^{\prime \prime}$ & $121^{\circ} 56^{\prime} 40^{\prime \prime}$ & $\begin{array}{l}02 / 25 / 10 \\
09 / 21 / 10\end{array}$ \\
\hline 7 & WRNO & 140.4 & 453630122021400 & $\begin{array}{l}\text { Columbia River, left bank, near Dodson, } \\
\text { Oregon (Warrendale) }\end{array}$ & $45^{\circ} 36^{\prime} 30^{\prime \prime}$ & $122^{\circ} 02^{\prime} 14^{\prime \prime}$ & Year-round \\
\hline 8 & CWMW & 121.7 & 453439122223900 & $\begin{array}{l}\text { Columbia River, right bank, at Washougal, } \\
\text { Washington (Camas) }\end{array}$ & $45^{\circ} 34^{\prime} 39^{\prime \prime}$ & $122^{\circ} 22^{\prime} 39^{\prime \prime}$ & $\begin{array}{l}02 / 25 / 10- \\
09 / 29 / 10\end{array}$ \\
\hline
\end{tabular}




\section{Methods of Data Collection}

Methods of data collection for TDG, barometric pressure, and water temperature are described in Tanner and Johnston (2001). A summary of these methods follows: Instrumentation at each monitoring station consists of a Hach Hydrolab water-quality probe, a Vaisala electronic barometer, a power supply, and a Sutron SatLink2 data-collection platform (DCP). The instruments at each station are powered by a 12-volt battery that is charged by a solar panel and (or) a 120-volt alternating-current line. Measurements (including probe depth) are made, logged, and transmitted every hour. The DCP transmits the most recent logged data to the Geostationary Operational Environmental Satellite (GOES) system (Jones and others, 1991). The data are automatically decoded and transferred to the USACE database and to the USGS database.

The eight fixed-station monitors were calibrated every 3 weeks, except from October 2009 through March 2010, when they were calibrated at 4-week intervals. At the beginning of the monitoring season in March, a new TDG membrane was installed on each Hydrolab. The field calibration procedure was as follows: A Hydrolab (which was calibrated several days before the field trip and used as a secondary standard) was deployed alongside of the field Hydrolab for a period of up to 1 hour to obtain check measurements of TDG and water temperature prior to removing the field Hydrolab (which had been deployed for 3 or 4 weeks). The field Hydrolab was then replaced with another Hydrolab that had been calibrated recently at the laboratory. The secondary standard was used again to check TDG and temperature measured by the newly deployed Hydrolab in the river. The equilibration process for the newly placed Hydrolab usually lasted about 1 hour. The electronic barometer at the fixed station was calibrated using a portable barometer (NovaLynx 230-M202) that had been calibrated to National Institute of Standards and Technology standards.

During each field calibration, the minimum compensation depth was calculated to determine whether the Hydrolab was positioned at an appropriate depth to measure TDG. This minimum compensation depth, which was calculated according to Colt (1984, p. 104), is the depth above which degassing will occur due to decreased hydrostatic pressure. To measure TDG accurately, the Hydrolabs were positioned at a depth below the calculated minimum compensation depth whenever possible.

The Hydrolab that was removed from the field after 3 or 4 weeks of deployment was then calibrated in the laboratory. The integrity of the TDG membrane was checked, and then the membrane was removed and air-dried. The TDG sensor (without the membrane attached) was calibrated at 0, 100, 200, and $300 \mathrm{~mm} \mathrm{Hg}$ (millimeters of mercury) above atmospheric pressure to cover the expected range of TDG in the river (approximately 100-, 113-, 126-, and 139-percent saturation, respectively).

\section{Summary of Total-Dissolved-Gas Data Completeness and Quality}

A summary of TDG data completeness and quality for water year 2010 is shown in table 2. Data in table 2 were based on the total amount of hourly TDG data that could have been collected during the monitoring season. Any hour without TDG pressure data or barometric pressure data was counted as an hour of missing data for TDG in percent saturation, which is calculated as TDG pressure divided by the barometric pressure (both in mm Hg) multiplied by 100. The fourth column in table 2 shows the percentages of data that were received in real time and passed quality-assurance checks. TDG data were considered to meet quality-assurance standards if they were within \pm (plus or minus) 1-percent saturation of the expected value, based on calibration data, replicate quality-control measurements in the river, and daily comparisons to ambient river conditions at adjacent stations. At each station, at least 98.4 per- 
cent of the data were received in real time and met quality-control checks, with an overall completeness of 99.7 percent (table 2). Stations with 2-4 hours of missing data in table 2 are the result of data that were deleted because the replacement Hydrolab did not equilibrate quickly.

Table 2. Total-dissolved-gas data completeness and quality, lower Columbia River, Oregon and Washington, water year 2010

[TDG, total dissolved gas]

\begin{tabular}{|c|c|c|c|}
\hline $\begin{array}{l}\text { Abbreviated } \\
\text { station name }\end{array}$ & $\begin{array}{l}\text { Planned } \\
\text { monitoring } \\
\text { in hours }\end{array}$ & $\begin{array}{c}\text { Number of } \\
\text { missing or deleted hour- } \\
\text { ly values }\end{array}$ & $\begin{array}{l}\text { Percentage of real-time } \\
\text { TDG data passing } \\
\text { quality assurance }\end{array}$ \\
\hline $\begin{array}{l}\text { John Day navigation lock } \\
\text { (JDY) }\end{array}$ & 4,703 & 2 & $100.0 \%$ \\
\hline $\begin{array}{l}\text { John Day tailwater } \\
\text { (JHAW) }\end{array}$ & 8,760 & 38 & $99.6 \%$ \\
\hline $\begin{array}{l}\text { The Dalles forebay } \\
\text { (TDA) }\end{array}$ & 4,799 & 22 & $99.5 \%$ \\
\hline $\begin{array}{l}\text { The Dalles tailwater } \\
\text { (TDDO) }\end{array}$ & 8,760 & 4 & $100.0 \%$ \\
\hline $\begin{array}{l}\text { Bonneville forebay } \\
\text { (BON) }\end{array}$ & 4,172 & 4 & $99.9 \%$ \\
\hline $\begin{array}{l}\text { Cascade Island } \\
\text { (CCIW) }\end{array}$ & 4,993 & 80 & $98.4 \%$ \\
\hline $\begin{array}{l}\text { Warrendale } \\
\text { (WRNO) }\end{array}$ & 8,760 & 4 & $100.0 \%$ \\
\hline $\begin{array}{l}\text { Camas } \\
\text { (CWMW) }\end{array}$ & 5,109 & 2 & $100.0 \%$ \\
\hline TOTAL & 50,056 & 156 & $99.7 \%$ \\
\hline
\end{tabular}

Table 3 lists the major portions of data that were either missing from the database (for example, when data collection failed) or data that were later deleted from the database because they did not meet quality-assurance standards. Table 3 includes TDG and temperature data, whereas table 2 includes only TDG data. A common cause for loss of data is the failure or tearing of the plastic tubing material that comprises the TDG membrane. This failure is easy to diagnose because the TDG pressure rises immediately to a high value, which results from water suddenly entering the membrane and exerting hydrostatic pressure (instead of the pressure of dissolved gases). 
Table 3. Major portions of missing or deleted data, lower Columbia River, Oregon and Washington, water year 2010

[USACE station identifier: JHAW, John Day tailwater; TDA, The Dalles forebay, CCIW, Cascade Island. Parameter abbreviations: TDG, total dissolved gas; WT, water temperature]

\begin{tabular}{lccc}
\hline \multicolumn{1}{c}{ Date and Time } & $\begin{array}{c}\text { USACE sta- } \\
\text { tion } \\
\text { identifier }\end{array}$ & Parameter & Reason / Notes \\
\hline $\begin{array}{l}\text { 2/28/10 08:00 } \\
\text { through }\end{array}$ & JHAW & TDG,WT & Problem with Hydrolab; it was replaced, but data not recovered \\
3/01/10 13:00 & & & \\
$\begin{array}{l}\text { 4/07/10 22:00 } \\
\text { through }\end{array}$ & TDA & TDG,WT, & $\begin{array}{l}\text { Intermittent transmission problem; DCP antenna and antenna cable } \\
\text { 4/13/10 13:00 }\end{array}$ \\
$\begin{array}{l}\text { (intermittent) } \\
\text { 7/26/10 05:00 }\end{array}$ & & & \\
$\begin{array}{l}\text { through } \\
\text { 7/28/10 09:00 }\end{array}$ & CCIW & TDG & Torn membrane; data not recovered \\
$\begin{array}{l}\text { 9/12/10 14:00 } \\
\text { through }\end{array}$ & & & \\
9/13/10 11:00 & CCIW & TDG & Torn membrane; data not recovered \\
\hline
\end{tabular}

The Cascade Island station had the most missing or deleted data. TDG data were lost at that station on two occasions and could not be recovered because of a torn TDG membrane. At the John Day tailwater station, there were communication problems between the DCP and the Hydrolab, so all data from the Hydrolab were missing for several days. At The Dalles forebay, there were some malfunctions with the data transmission, so the DCP antenna and antenna cable were replaced.

\section{Quality-Assurance Data}

Data collection for TDG, barometric pressure, and water temperature involve several qualityassurance procedures, including calibration of instruments in the field and in the laboratory, daily checks of the data, and data review and archive. These methods are explained in detail in Tanner and Johnston (2001), and the results of the quality-assurance data for water year 2010 are presented in this section.

After field deployment for 3 or 4 weeks, the TDG sensors were calibrated in the laboratory. First, the instrument was tested, with the membrane in place, for response to supersaturation conditions. The membrane was then removed from the sensor and allowed to dry for approximately 24 hours. Before replacing the membrane, the TDG sensor was examined independently. The calibration test procedure compared the reading of the TDG sensor to barometric pressure (100-percent saturation). Using a certified digital pressure gage (primary standard), comparisons also were made at pressures of 100, 200, and $300 \mathrm{~mm} \mathrm{Hg}$ above barometric pressure (approximately 113-, 126-, and 139-percent saturation, respectively). The accuracy of the TDG sensors was calculated by computing the difference between the primary standard and the TDG sensor reading (expected minus actual) for each of the four test conditions, dividing by the barometric pressure, and multiplying by 100 . All sensor readings were within 0.5percent saturation (fig. 2). Of the 105 laboratory checks that were performed, only 2 checks had a difference more than $2 \mathrm{~mm} \mathrm{Hg}$ compared to the primary standard. One of those checks was different by 2.1 $\mathrm{mm} \mathrm{Hg}$ and the other by $2.4 \mathrm{~mm} \mathrm{Hg}$. 


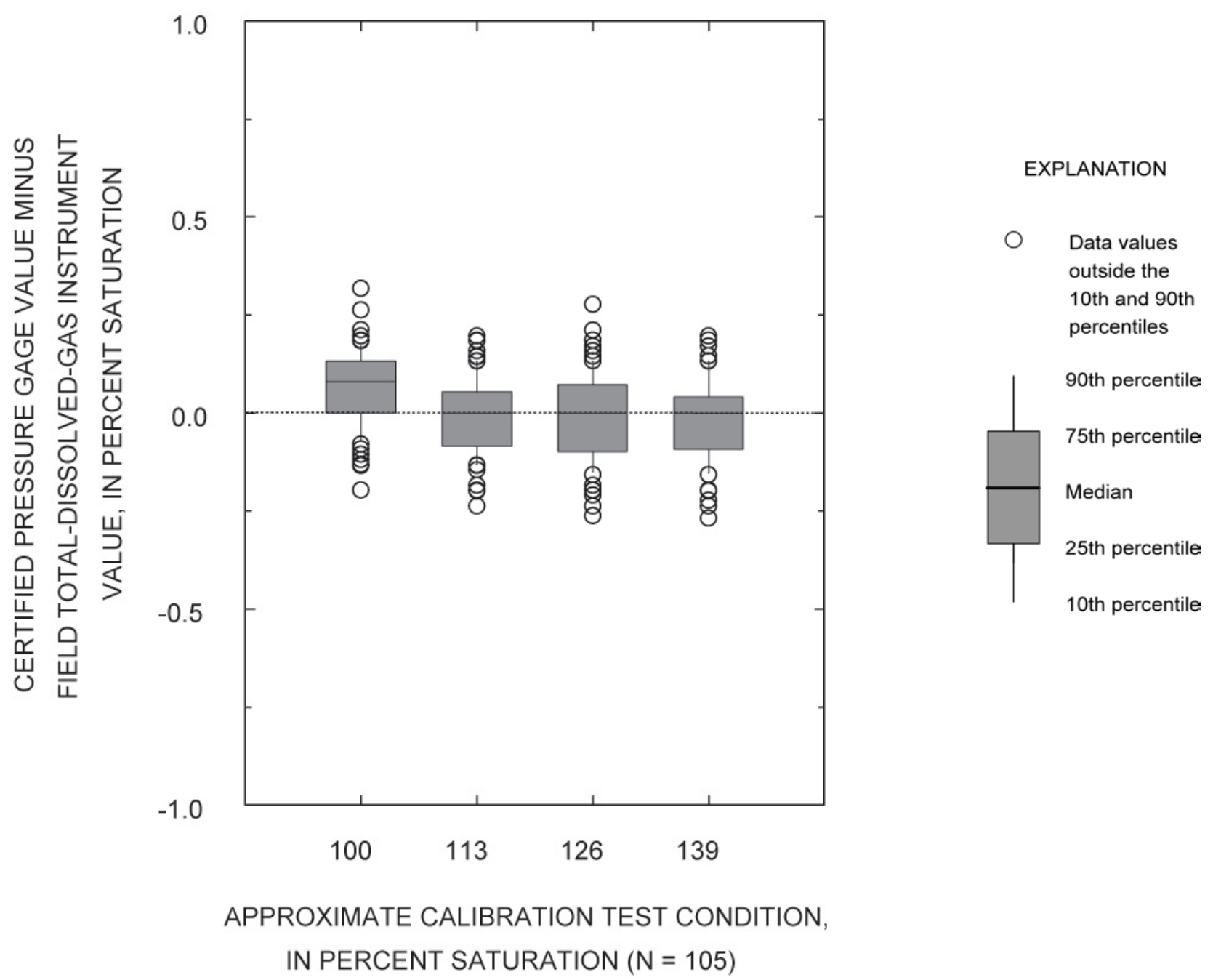

Figure 2. Boxplot showing accuracy of total-dissolved-gas sensors in the laboratory after 3 or 4 weeks of field deployment at eight monitoring stations in the lower Columbia River, Oregon and Washington, water year 2010 (number of comparison values $=105$ ). 
The differences in barometric pressure, in situ water temperature, and in situ TDG between the secondary standard instruments and the fixed-station monitors after field deployment were measured and recorded as part of the field inspection and calibration procedure. These differences, calculated as the secondary standard values minus the field instrument values, were used to compare and quantify the accuracy and precision between the two instruments. For water temperature and TDG, the measurements were made in situ with the secondary standard (a recently calibrated Hydrolab) positioned alongside the field Hydrolab in the river. A digital barometer, NIST certified through February 2011, served as the primary standard for barometric pressure. Figures 3, 4, and 5 illustrate the distribution of qualityassurance data for each of the three parameters from all eight stations.

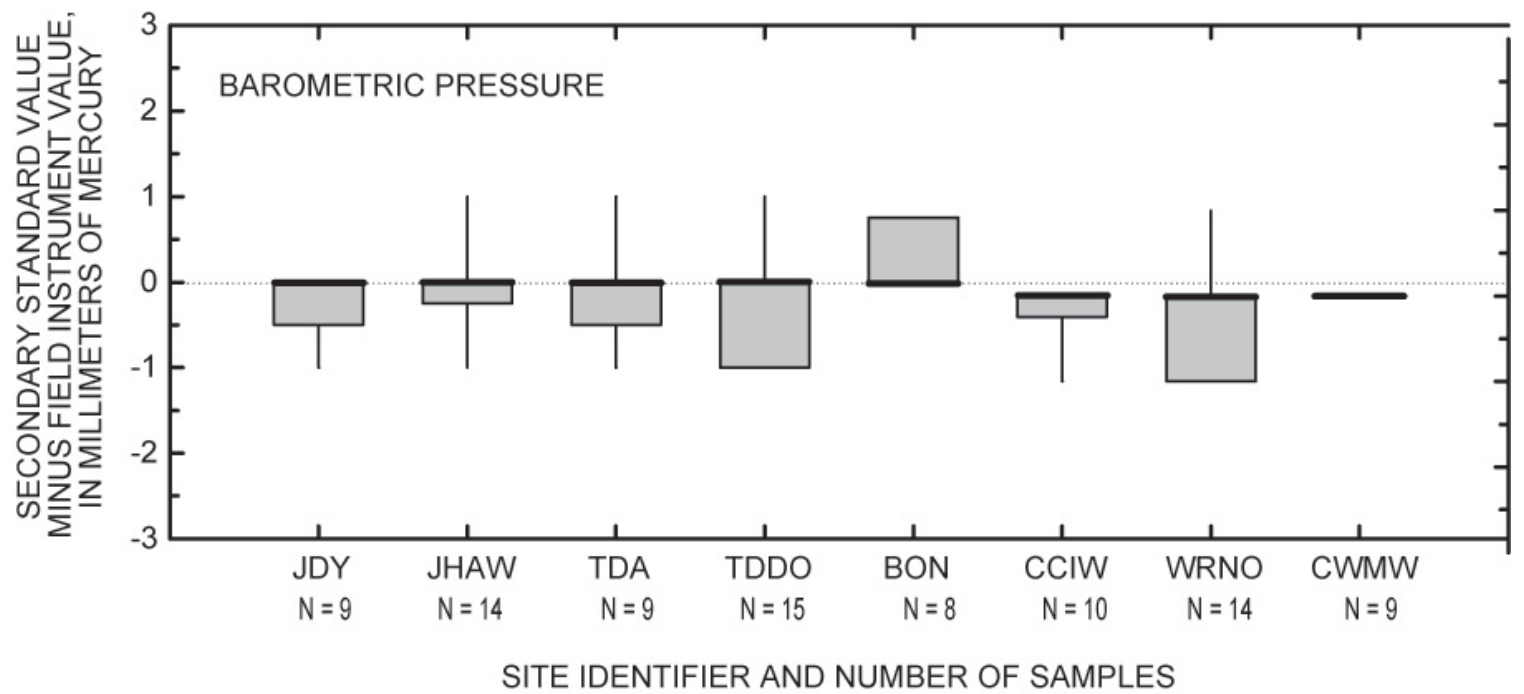

Figure 3. Boxplot showing difference between the secondary standard and the field barometers in the field after 3 or 4 weeks of field deployment at eight stations in the lower Columbia River, Oregon and Washington, water year 2010.

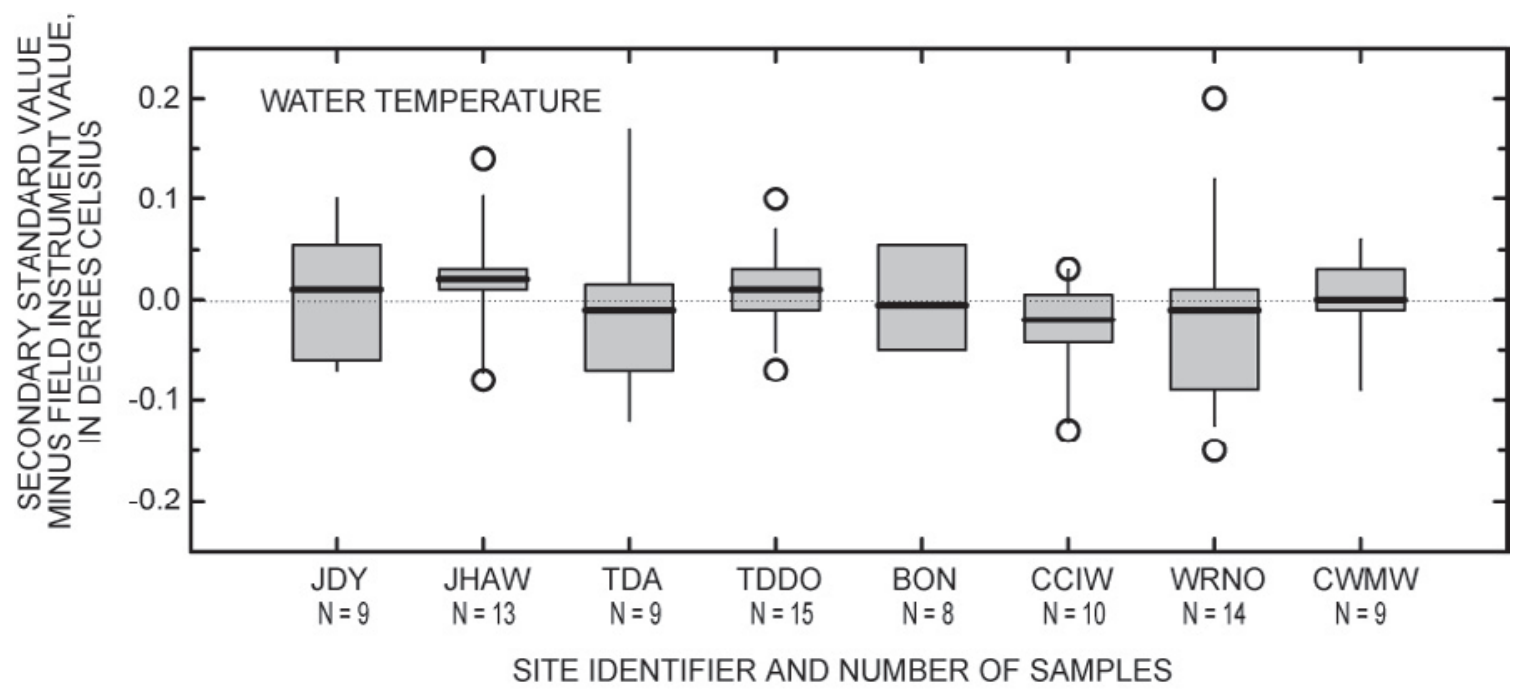

Figure 4. Boxplot showing difference between the secondary standard and the field temperature instruments in the field after 3 or 4 weeks of field deployment at eight stations in the lower Columbia River, Oregon and Washington, water year 2010. 
The comparisons of the digital barometer and the field barometers are shown in figure 3 . All field values were within $1 \mathrm{~mm} \mathrm{Hg}$ of standard values. The secondary standard temperature sensor and the field temperature sensor results are presented in figure 4 . All differences were within $0.2^{\circ} \mathrm{C}$.

Differences between the secondary standard TDG sensor and the field TDG sensors were calculated following equilibration of the secondary standard unit to the onsite conditions before removing the field unit. The side-by-side equilibrium was considered complete after a minimum of 20 minutes when the TDG values for each sensor remained constant for 2 minutes.

All but one of the field checks show less than 2.0-percent saturation difference between the two TDG sensors (fig. 5). The greatest difference was +2.1-percent saturation at the John Day forebay station on April 5, 2010 during low dissolved gas conditions prior to the beginning of spill season. Four of the field checks showed between 1.0- and 2.0-percent saturation differences. Two of these occurred at the Dalles tailwater station, where low streamflow velocity often results in slow equilibration of the reference sensor during elevated dissolved-gas conditions. The third instance occurred at the Cascade Island station, also as a result of slow equilibration of the reference sensor. The fourth example occurred at the Warrendale station. The sensor that was about to be removed after 3 weeks of deployment read low compared to the reference sensor and there appeared to be moisture within the membrane.

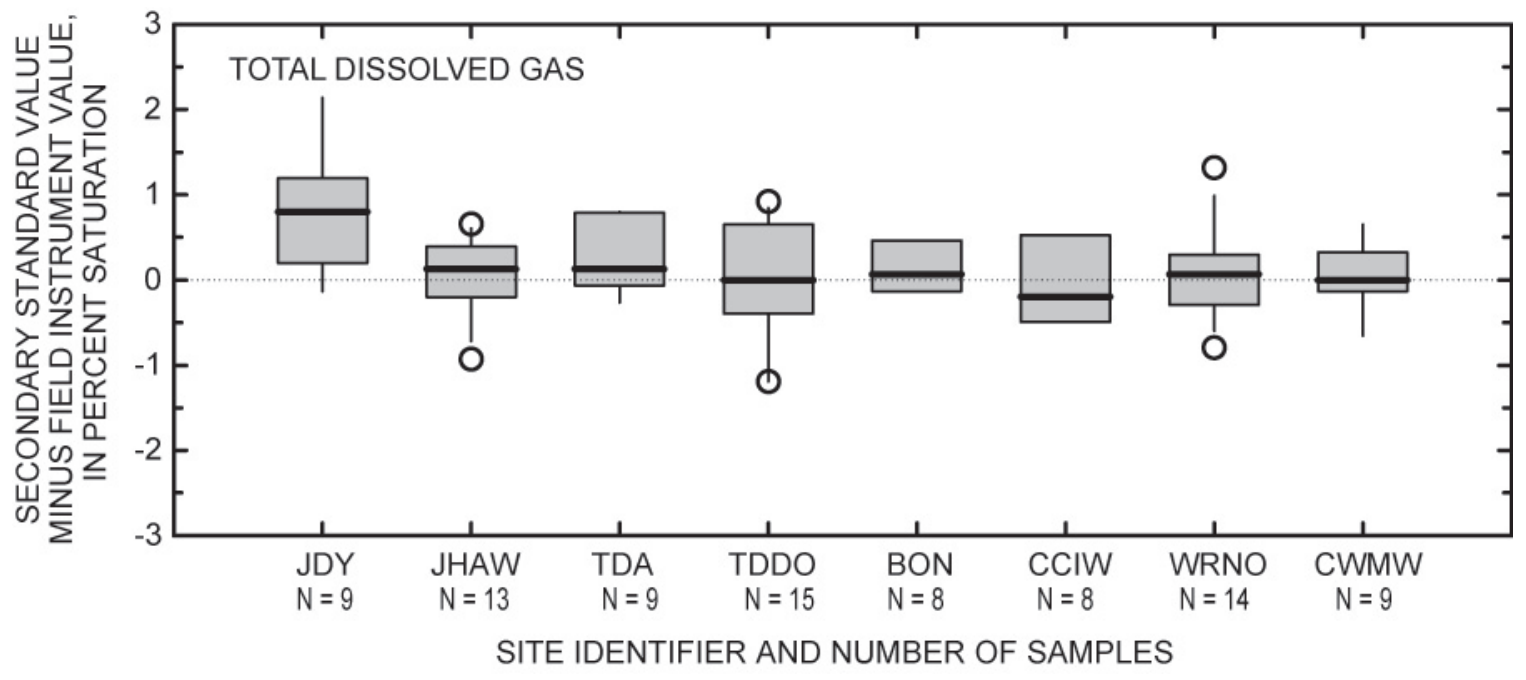

Figure 5. Boxplot showing difference between the secondary standard and the field total-dissolvedgas instruments in the field after 3 or 4 weeks of field deployment at eight stations in the lower Columbia River, Oregon and Washington, water year 2010. 


\section{Effects of Spill on Total-Dissolved-Gas Concentration}

The graph of spill from John Day Dam and the TDG at the John Day Dam tailwater station shows a fairly linear relation at spills larger than about 70,000 $\mathrm{ft}^{3} / \mathrm{s}$ (fig. 6). However, at spills below that amount, the relation is not linear. TDG was at or below 120 percent saturation at spills up to about $150,000 \mathrm{ft}^{3} / \mathrm{s}$.

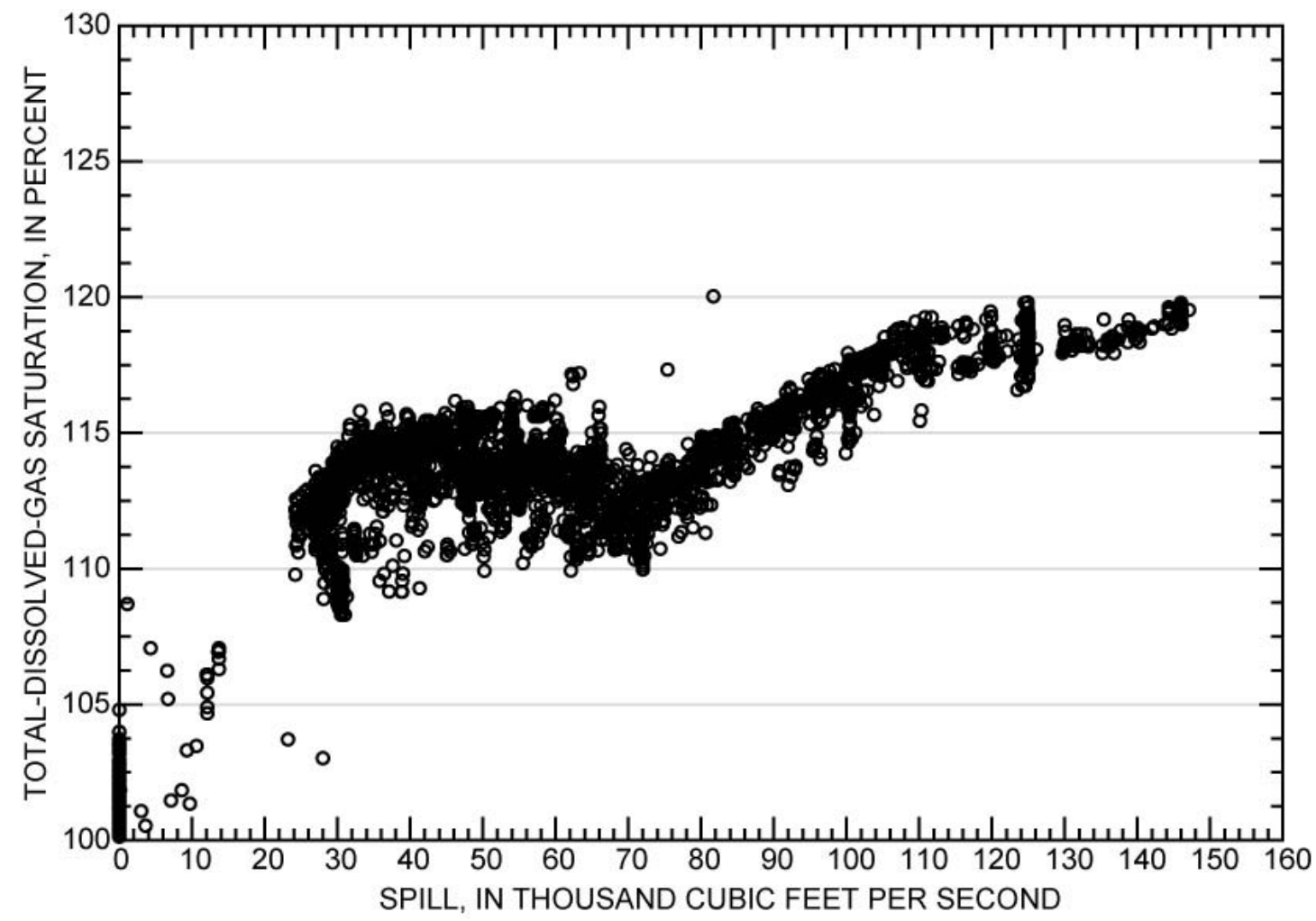

Figure 6. Graph showing relation of total-dissolved-gas saturation downstream of John Day Dam and spill from John Day Dam, lower Columbia River, Oregon and Washington, April 1-August 31, 2010.

The relations between spill and TDG at the other dams at the corresponding tailwater station or stations were fairly linear for The Dalles Dam (fig. 7,on page 12) and Bonneville Dam (figs. 8 and 9). At spills greater than about 130,000 $\mathrm{ft}^{3} / \mathrm{s}$, TDG at The Dalles Dam tailwater rarely exceeded 120 percent saturation. At Cascade Island, spills greater than $90,000 \mathrm{ft}^{3} / \mathrm{s}$ exceeded 120 percent saturation, whereas TDG at Warrendale only occasionally exceeded 120 percent saturation at spills in excess of 150,000 $\mathrm{ft}^{3} / \mathrm{s}$. 


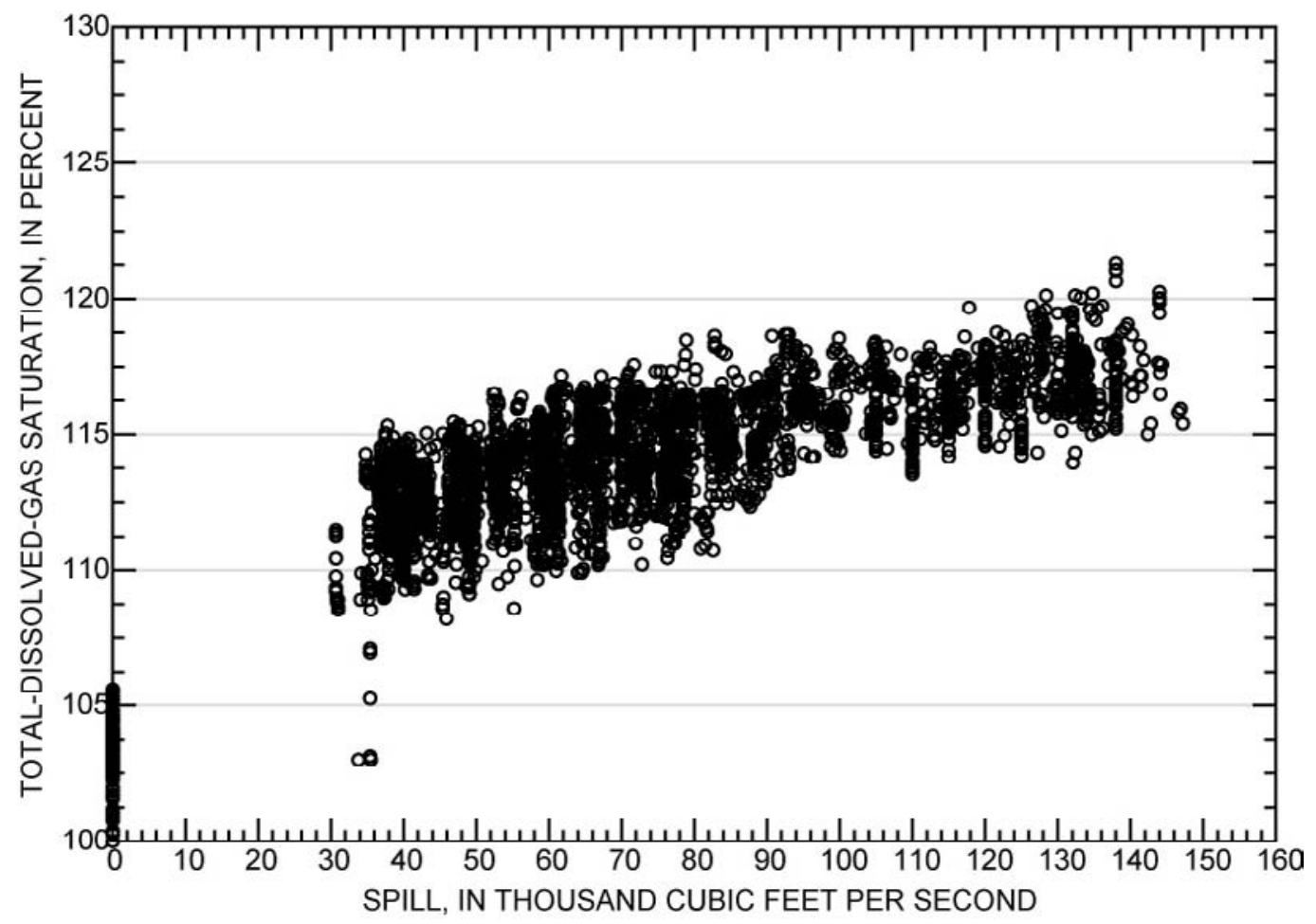

Figure 7. Graph showing relation of total-dissolved-gas saturation downstream of The Dalles Dam and spill from The Dalles Dam, lower Columbia River, Oregon and Washington, April 1 August 31, 2010.

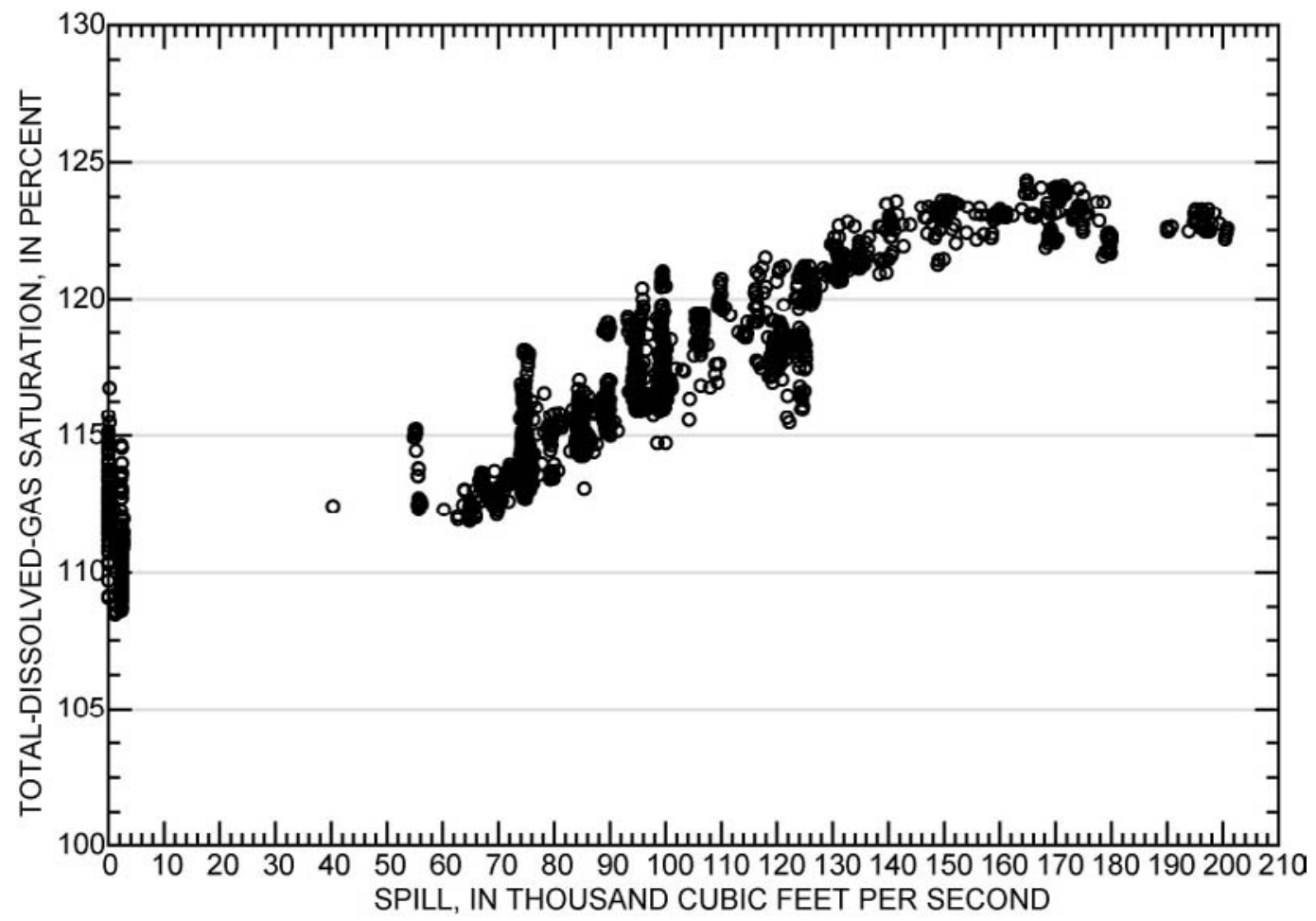

Figure 8. Graph showing relation of total-dissolved-gas saturation downstream of Bonneville Dam at Cascade Island and spill from Bonneville Dam, lower Columbia River, Oregon and Washington, April 1-August 31, 2010 


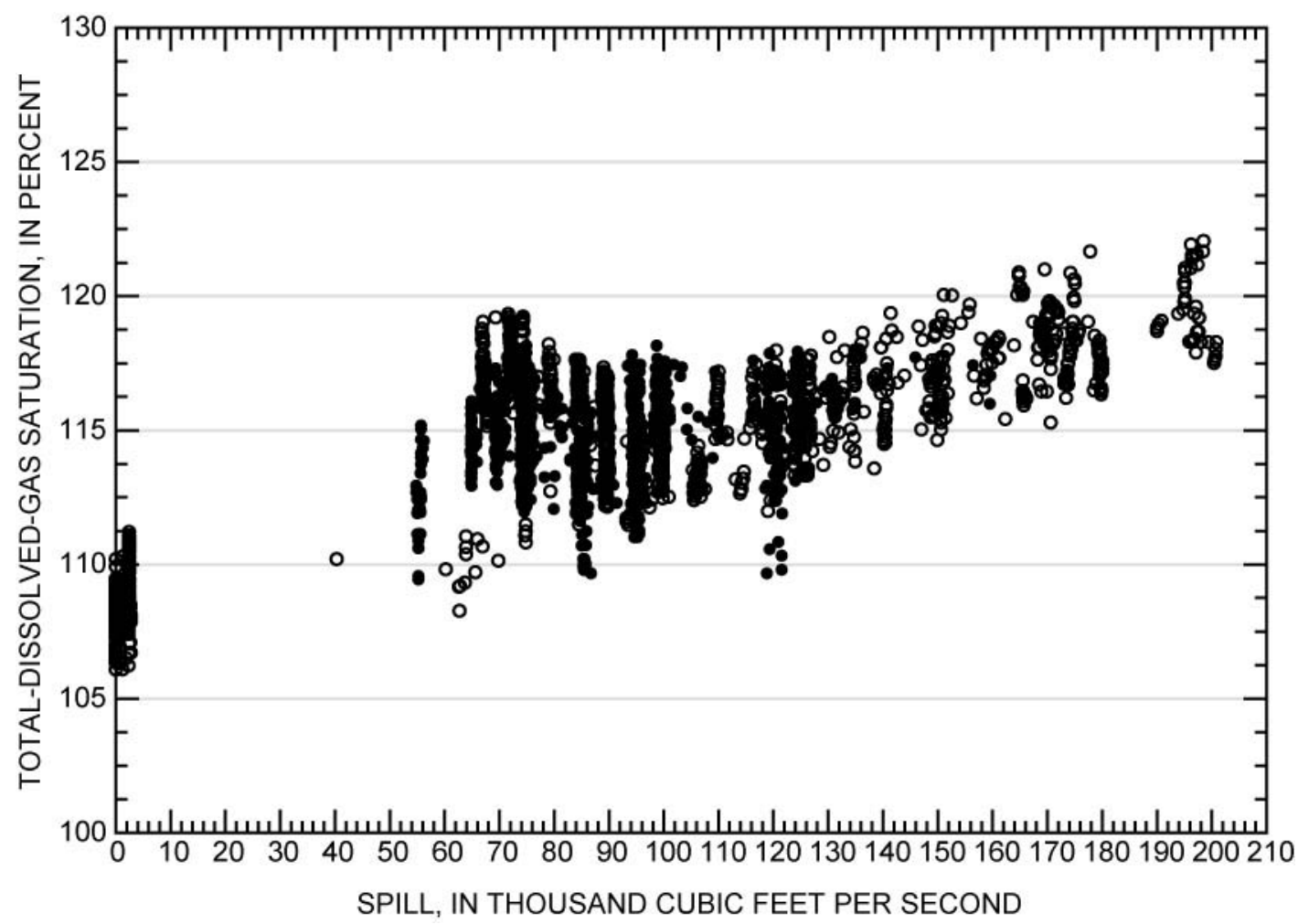

Figure 9. Graph showing relation of total-dissolved-gas saturation downstream of Bonneville Dam at Warrendale and spill from Bonneville Dam, lower Columbia River, Oregon and Washington, April 1-August 31, 2010

\section{Comparison of Total-Dissolved-Gas Concentration and Temperature to Standards}

In 2010, variances or waivers were granted to the water-quality standard for TDG of 110-percent saturation. These variances were established to allow spill for fish passage at dams on the Columbia River. The State of Oregon granted a 5-year variance for 2010 through 2014 (State of Oregon, 2009). The State of Washington provided for fish passage in its water-quality standards consistent with approved gas-abatement plans through February 2010 (State of Washington, 2006a). From April 1 to August 31, 2010, the USACE was granted variances allowing TDG to reach 115-percent saturation for forebay stations (John Day Dam navigation lock, The Dalles Dam forebay, Bonneville Dam forebay, and Camas) and 120-percent saturation for tailwater stations, directly downstream of dams (John Day Dam tailwater, The Dalles Dam tailwater, Cascade Island, and Warrendale). The 115- and 120-percent variances were exceeded if the average of the highest 12 hourly values in 1 day (1:00 a.m. to midnight) (Oregon variance) or 12 highest consecutive hourly readings in any 24-hour period (Washington variance) was larger than the numerical standard. A separate variance of 125 percent was in place for all stations for the highest 2-hour average (Oregon Environmental Quality Commission, written commun., 2007), or the highest 1-hour average (State of Washington, 2006a). Although the Camas station is not located at the forebay of a dam, it is $24.4 \mathrm{mi}$ downstream of Bonneville Dam and is regulated as a forebay station. 
The distribution of hourly TDG values for the spill season (April 1 through August 31, 2010) is shown in figure 10. The applicable variance is shown with the data for each station. The variances apply to an average value, whereas the distribution plots show the hourly values. Consequently, the points outside of the variances on the graph do not necessarily represent actual exceedances of the variances.

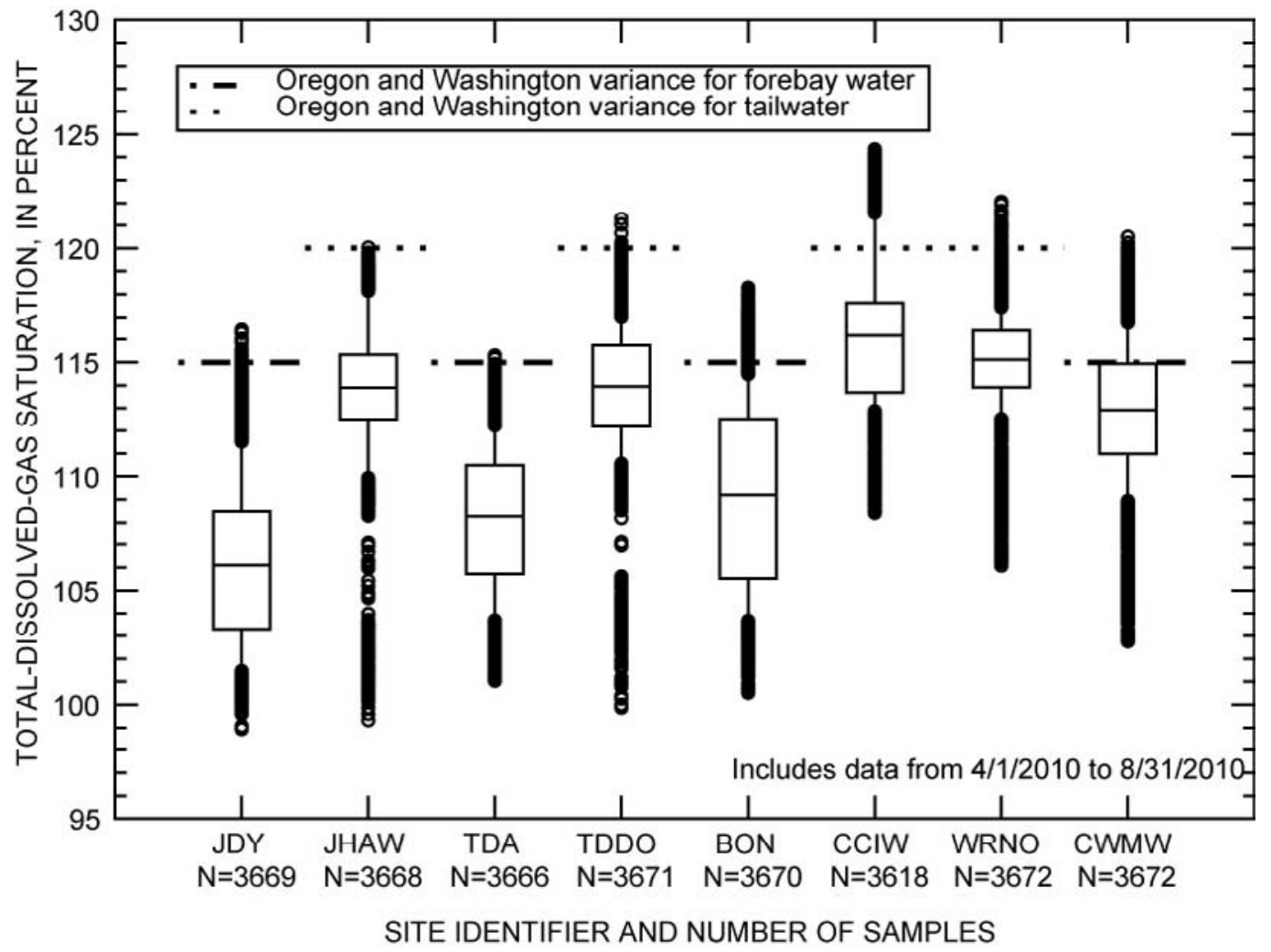

Figure 10. Boxplot showing distributions of hourly total-dissolved-gas data and Oregon and Washington water-quality variances, lower Columbia River, Oregon and Washington, April 1August 31, 2010.

Data from the forebay stations in figure 10 show an increase in the median and 75-percent quartile TDG levels (from John Day Dam to The Dalles Dam to Bonneville Dam to Camas), which probably reflects the river's inability to de-gas downstream of each dam before another dam is encountered to again cause an increase in TDG. Some of the highest hourly values of TDG were measured at Cascade Island, which is a tailwater station that is located only 0.2 mile downstream from Bonneville Dam. The other tailwater stations are at least 1 mile or more downstream from their respective dams. None of the stations had hourly values that exceeded 125 percent saturation.

Figures 11-18 show the timing of the occurrence of exceedances (high 12-hour daily average for comparison to the Oregon variance) and spill at the closest upstream dam. For the calculations of the high 12-hour average, missing TDG data were ignored and the next adjacent data points were used to calculate whether an exceedance had occurred. The figures are in order from upstream to downstream, and in the cases of the forebay stations, the spill data provided are from a dam several miles upstream. Several stations had exceedances on more than just a few days: Bonneville forebay, Cascade Island, and Camas. 

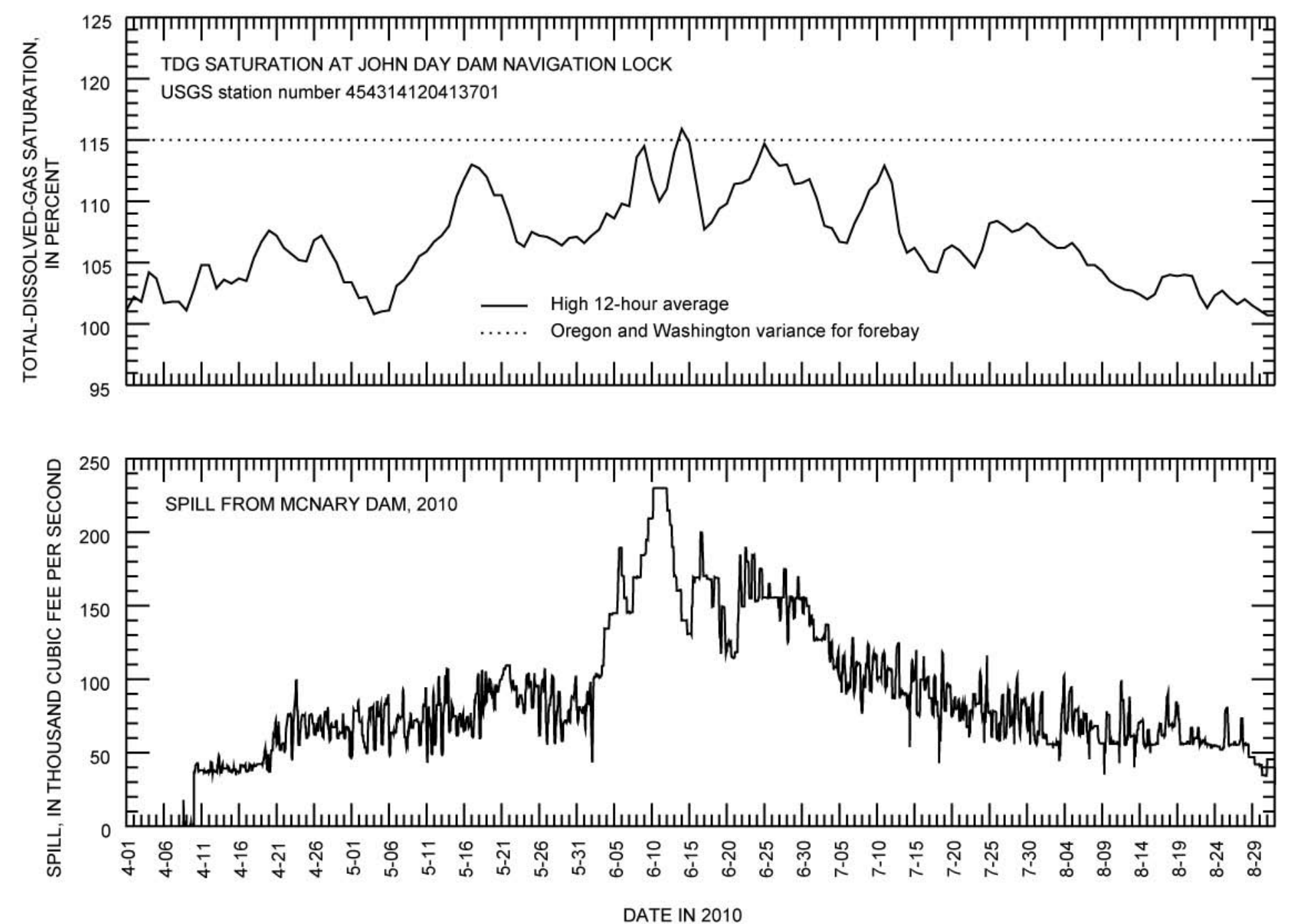

Figure 11. Graphs showing total-dissolved-gas saturation at John Day Dam navigation lock and spill from McNary Dam (76 river miles upstream from John Day Dam), lower Columbia River, Oregon and Washington, April 1-August 31, 2010. 

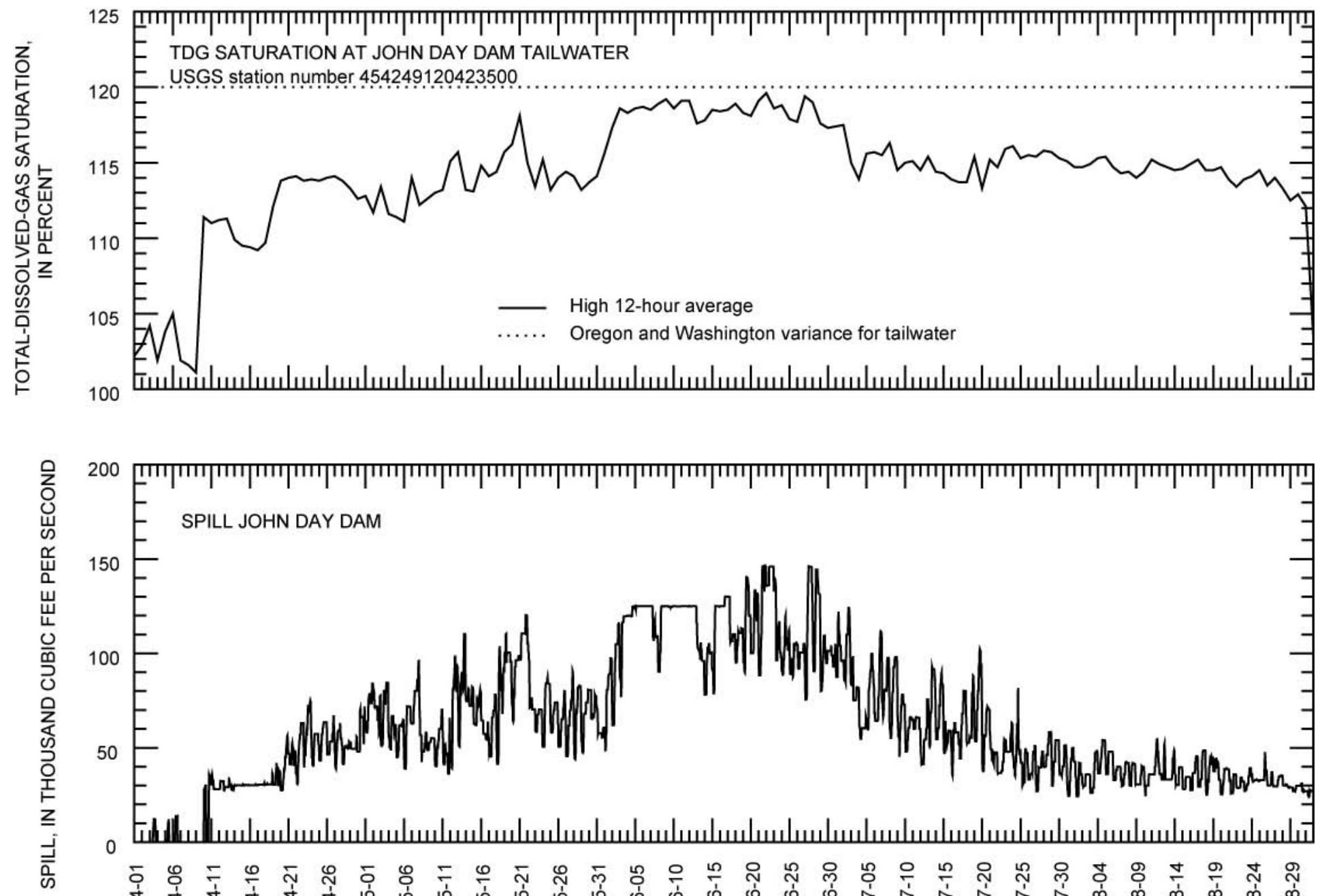

DATE IN 2010

Figure 12. Graphs showing total-dissolved-gas saturation at John Day Dam tailwater and spill from John Day Dam, lower Columbia River, Oregon and Washington, April 1-August 31, 2010. 

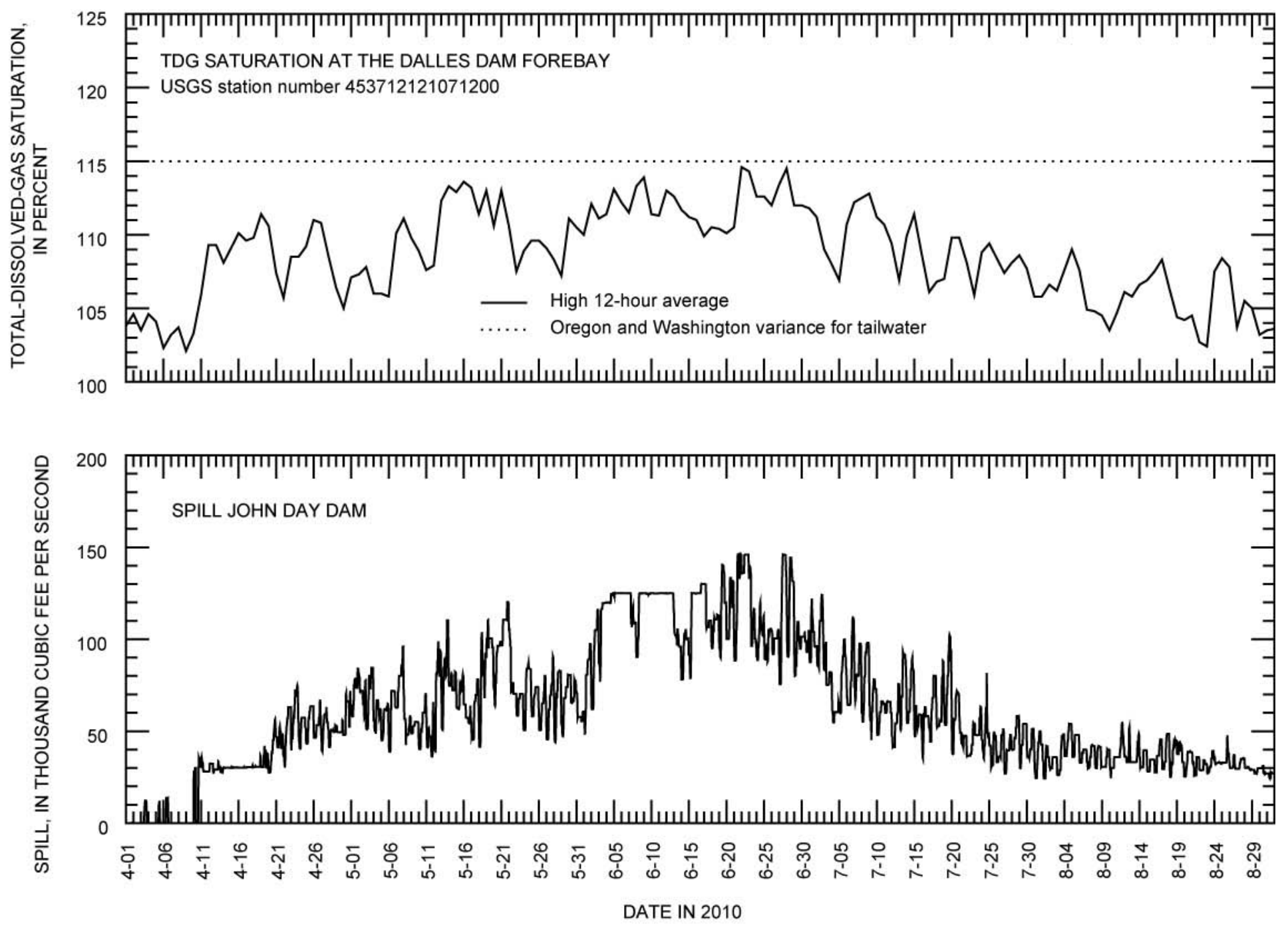

Figure 13. Graphs showing total-dissolved-gas saturation at The Dalles Dam forebay and spill from John Day Dam, lower Columbia River, Oregon and Washington, April 1-August 31, 2010. 

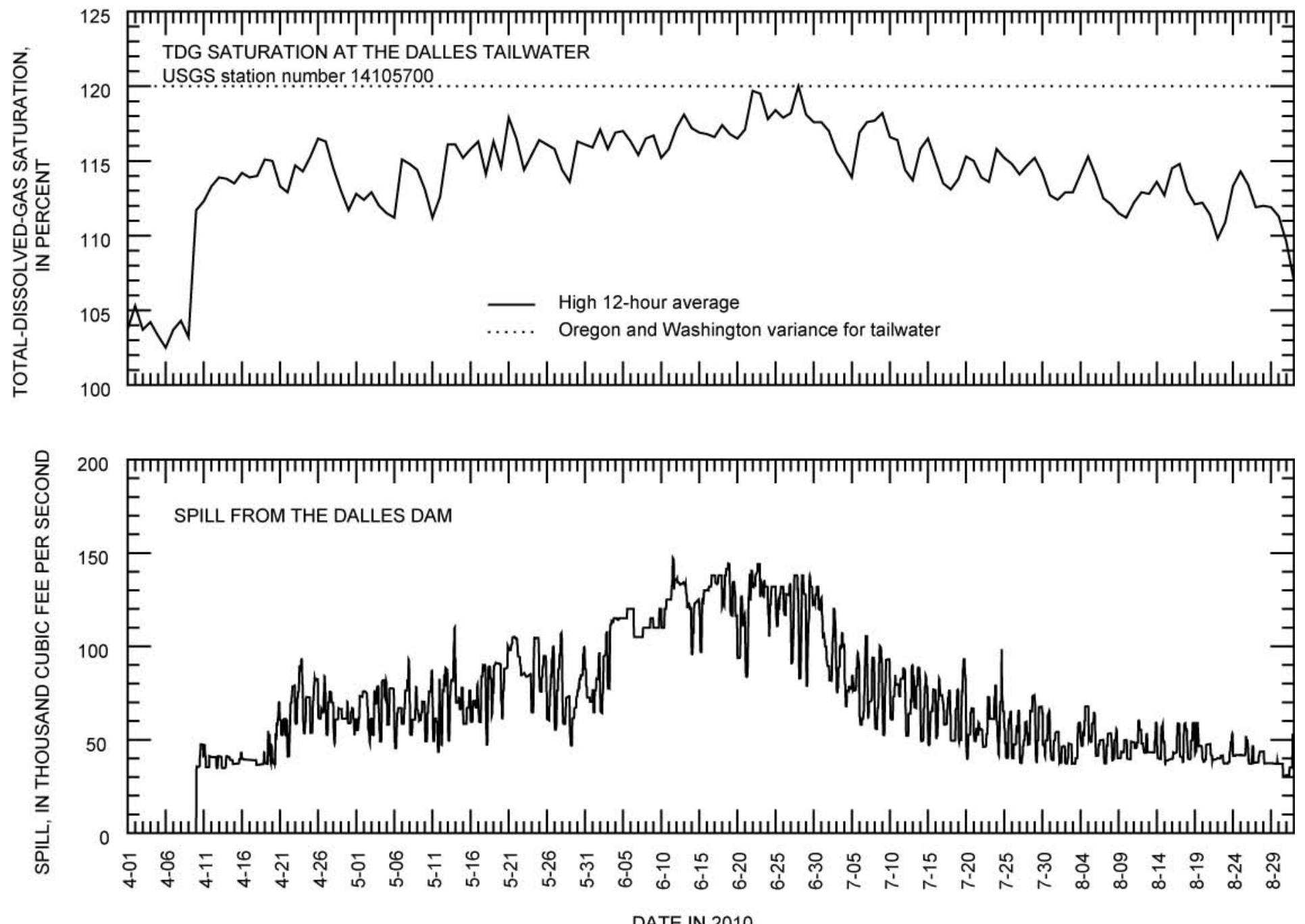

Figure 14. Graphs showing total-dissolved-gas saturation at The Dalles Dam tailwater and spill from The Dalles Dam, lower Columbia River, Oregon and Washington, April 1-August 31, 2010. 

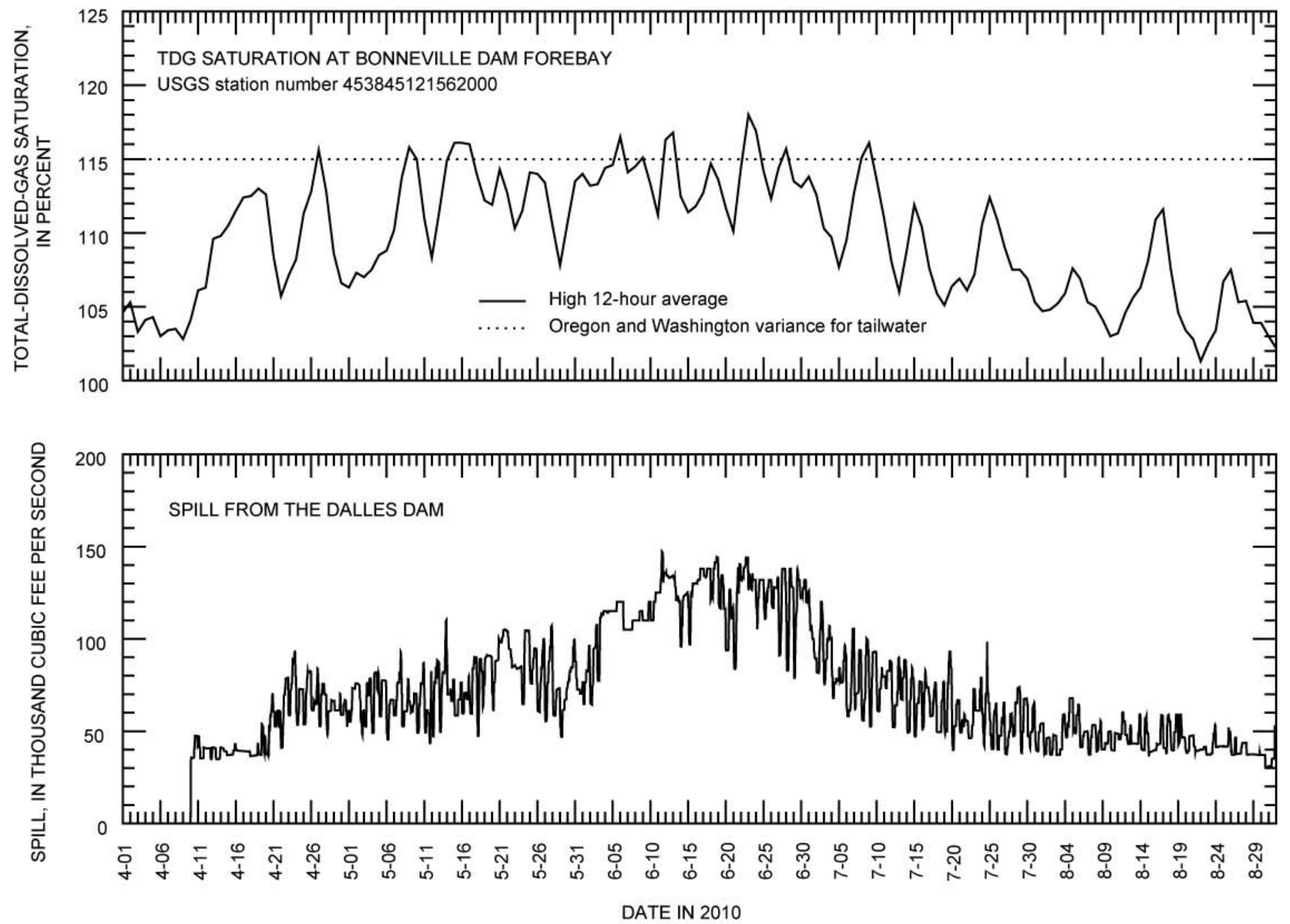

Figure 15. Graphs showing total-dissolved-gas saturation at Bonneville Dam forebay and spill from The Dalles Dam, lower Columbia River, Oregon and Washington, April 1-August 31, 2010 

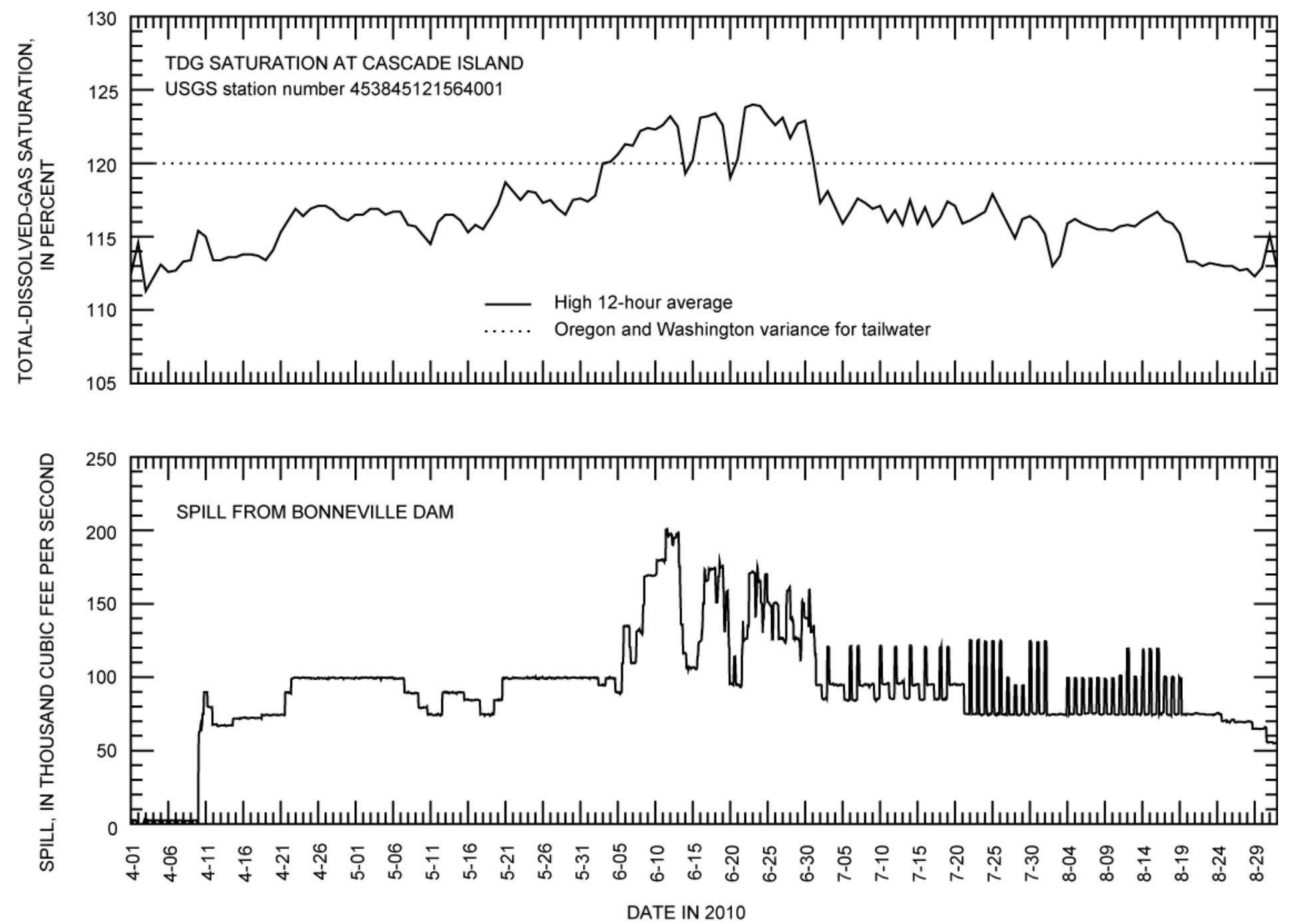

Figure 16. Graphs showing total-dissolved-gas saturation at Cascade Island and spill from Bonneville Dam, lower Columbia River, Oregon and Washington, April 1-August 31, 2010 

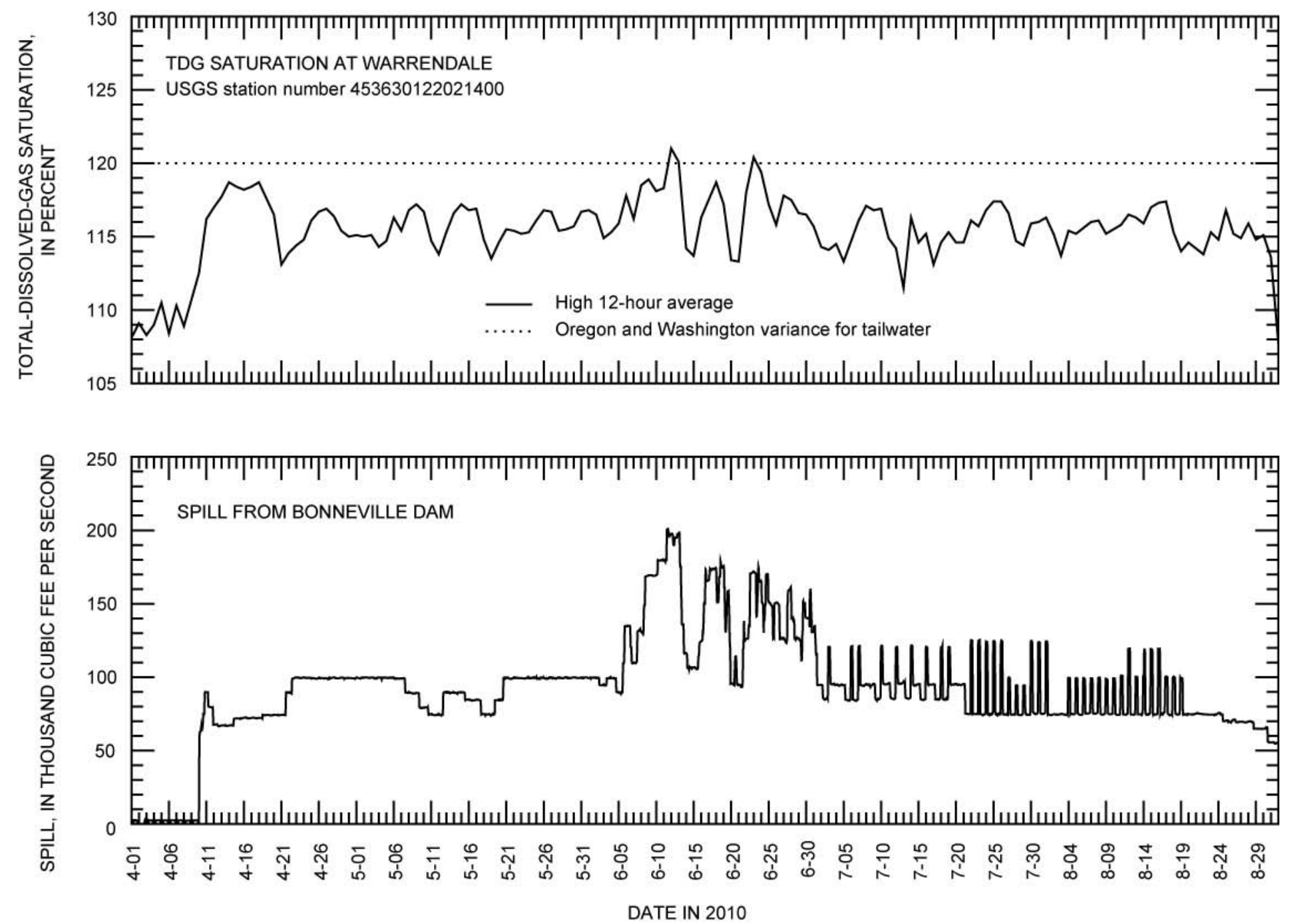

Figure 17. Graphs showing total-dissolved-gas saturation at Warrendale and spill from Bonneville Dam, lower Columbia River, Oregon and Washington, April 1-August 31, 2010 

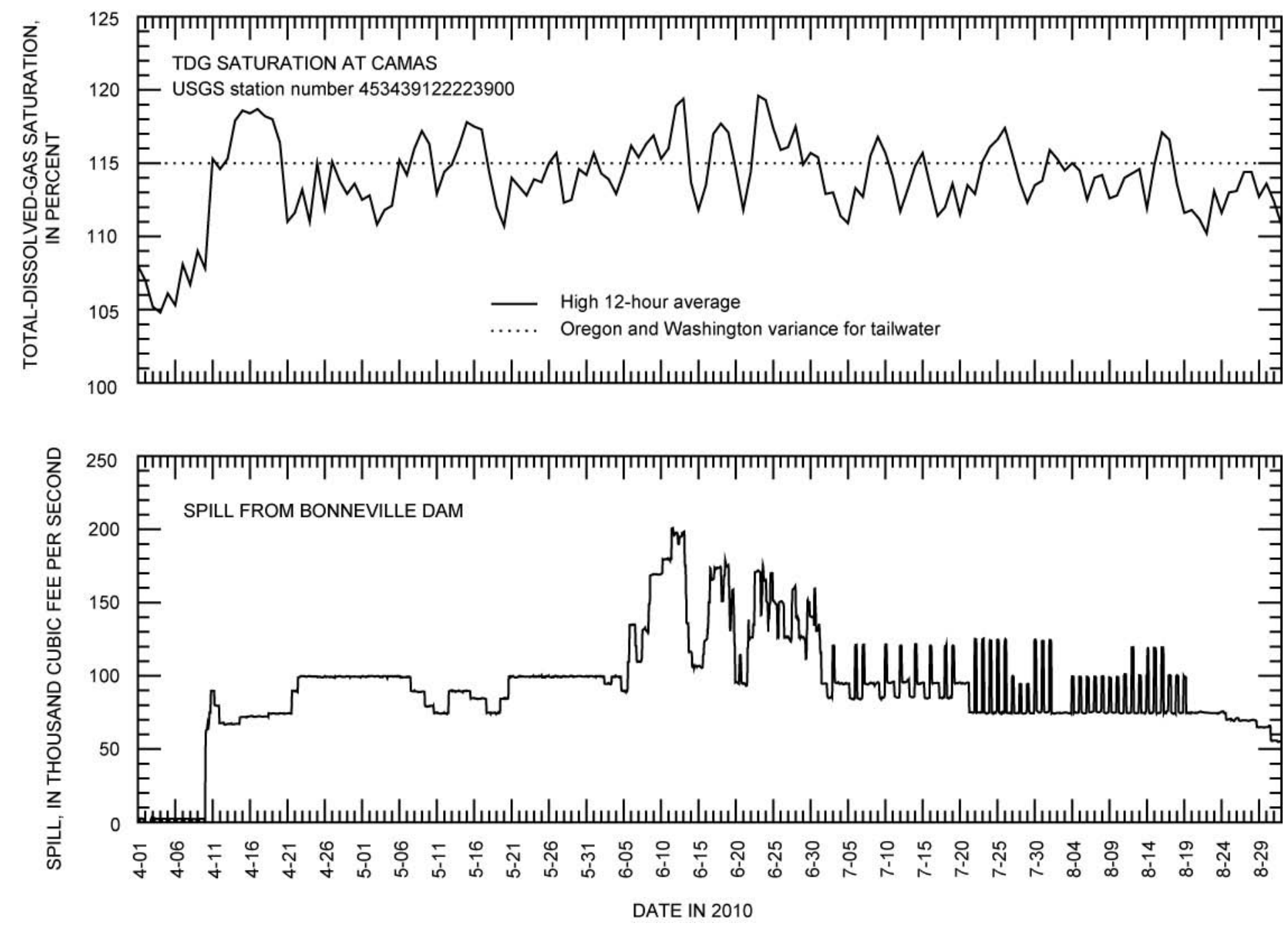

Figure 18. Graphs showing total-dissolved-gas saturation at Camas and spill from Bonneville Dam, lower Columbia River, Oregon and Washington, April 1-August 31, 2010 
Water-temperature standards that apply to the lower Columbia River are complex and depend on the effects of human activities and the locations of salmonid rearing, spawning, and egg incubation areas. According to the State of Oregon water-temperature standard, the 7-day-average maximum temperature of the lower Columbia River should not exceed $20^{\circ} \mathrm{C}$ (State of Oregon, 2008). Washington State regulations mandate that the water temperature in the Columbia River shall not exceed a 1-day maximum of $20.0^{\circ} \mathrm{C}$ due to human activities (State of Washington, 2006b).

This report deals only with the hourly values for water temperature. Water temperatures upstream and downstream of John Day Dam (fig. 19), The Dalles Dam (fig. 20), and Bonneville Dam (figs. 21 and 22), and at Camas (fig. 23) were greater than $20.0^{\circ} \mathrm{C}$ from late July through late August or early September. Water temperatures at the forebay stations were approximately equal to the temperatures at the tailwater stations (except during short time periods at the John Day Dam navigation lock), indicating that the sensors were placed in well-mixed conditions in the forebays and tailwater stations.

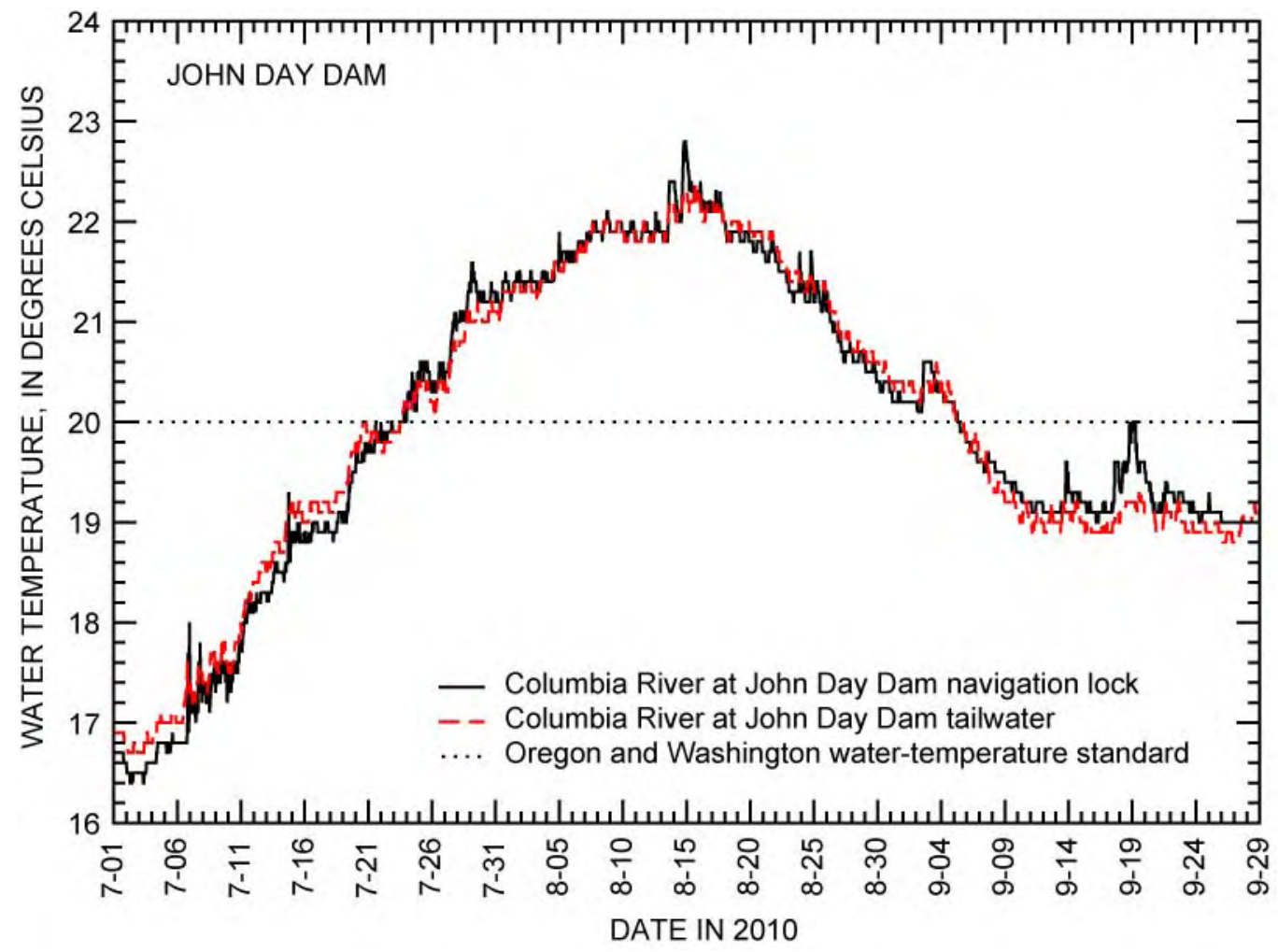

Figure 19. Graph showing water temperature upstream of John Day Dam and downstream of John Day Dam, lower Columbia River, Oregon and Washington, summer 2010. 


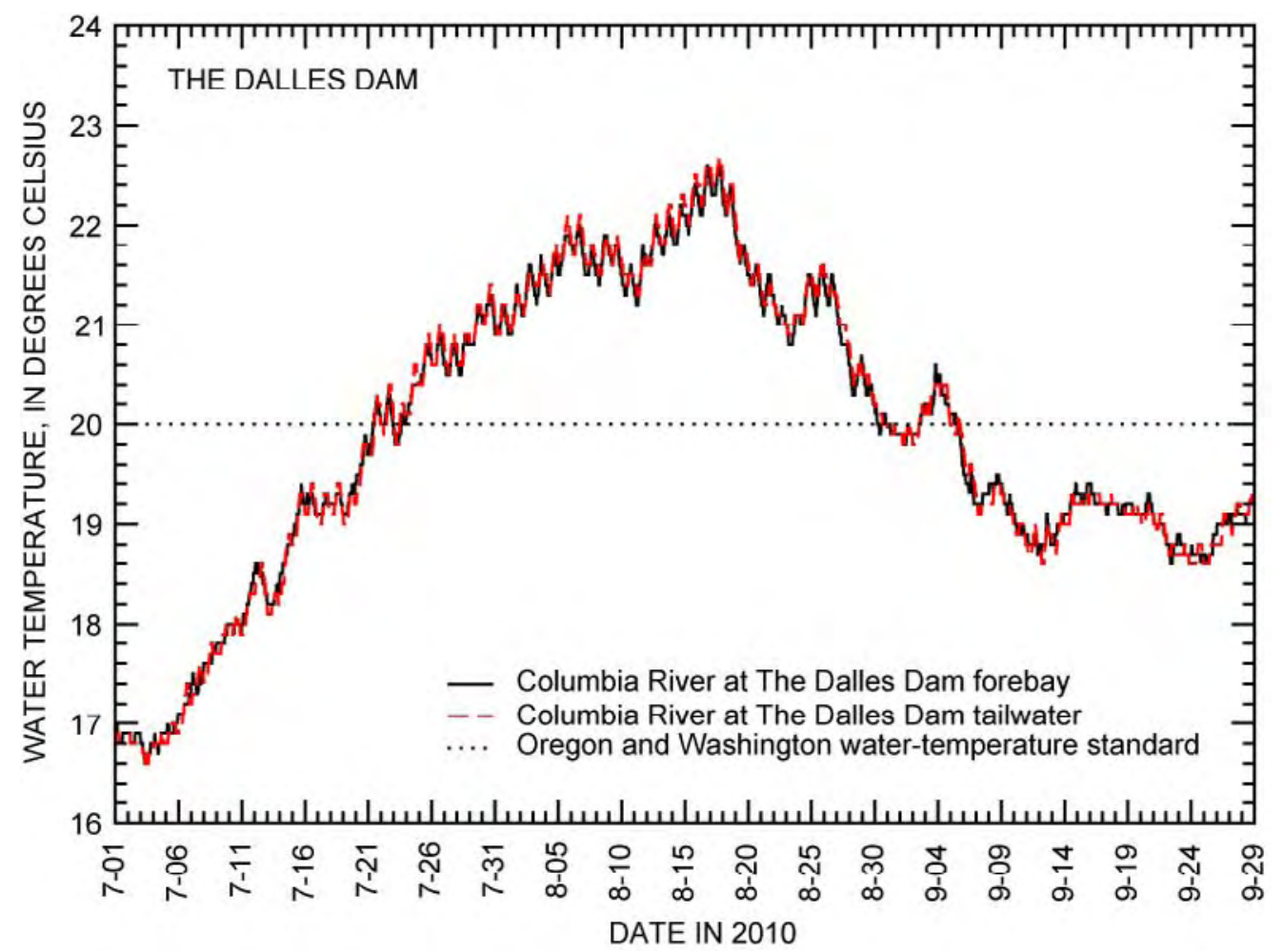

Figure 20. Graph showing water temperature upstream and downstream of The Dalles Dam, lower Columbia River, Oregon and Washington, summer 2010.

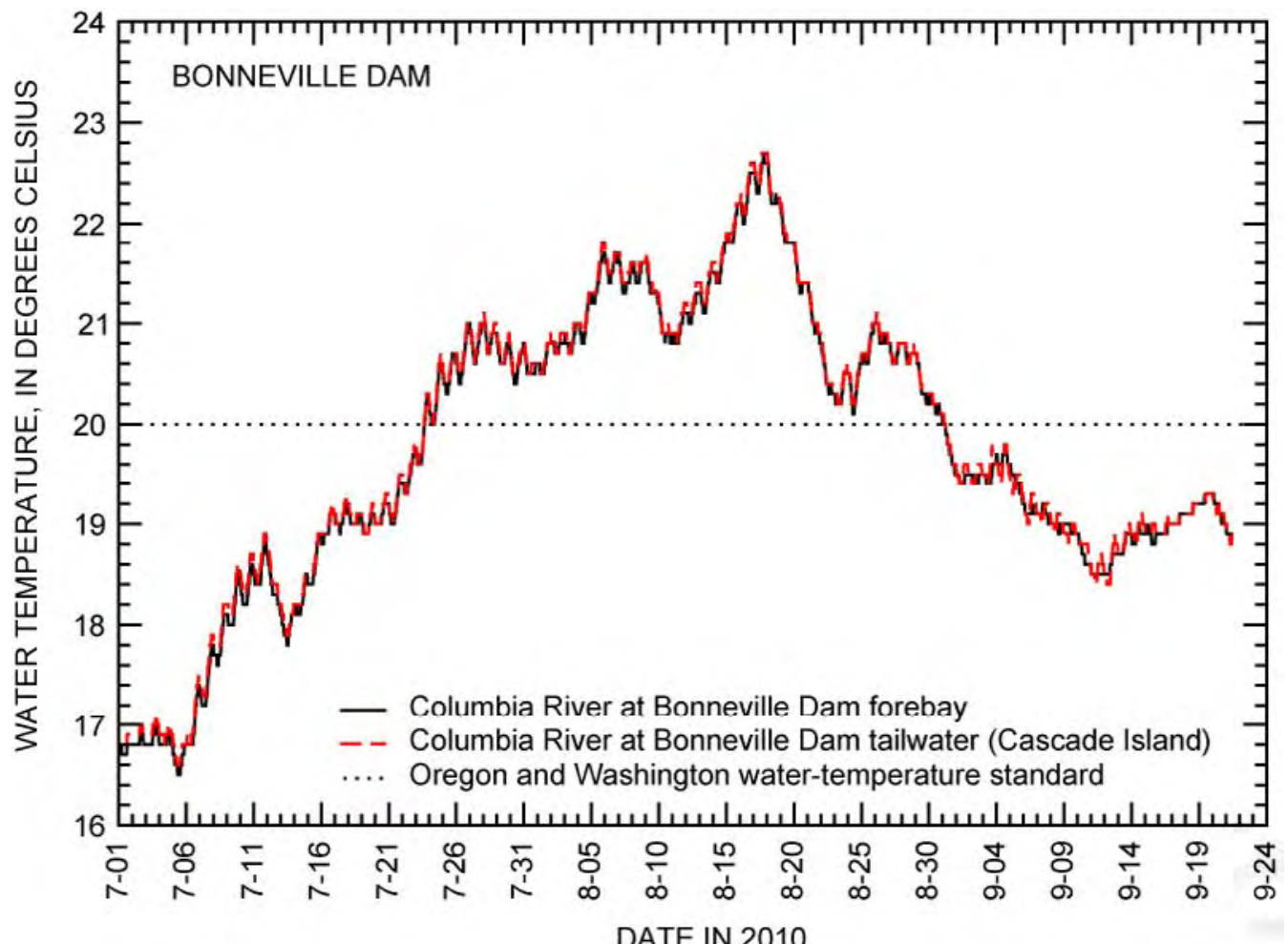

Figure 21. Graph showing water temperature upstream of Bonneville Dam and downstream of Bonneville Dam at Cascade Island, lower Columbia River, Oregon and Washington, summer 2010 


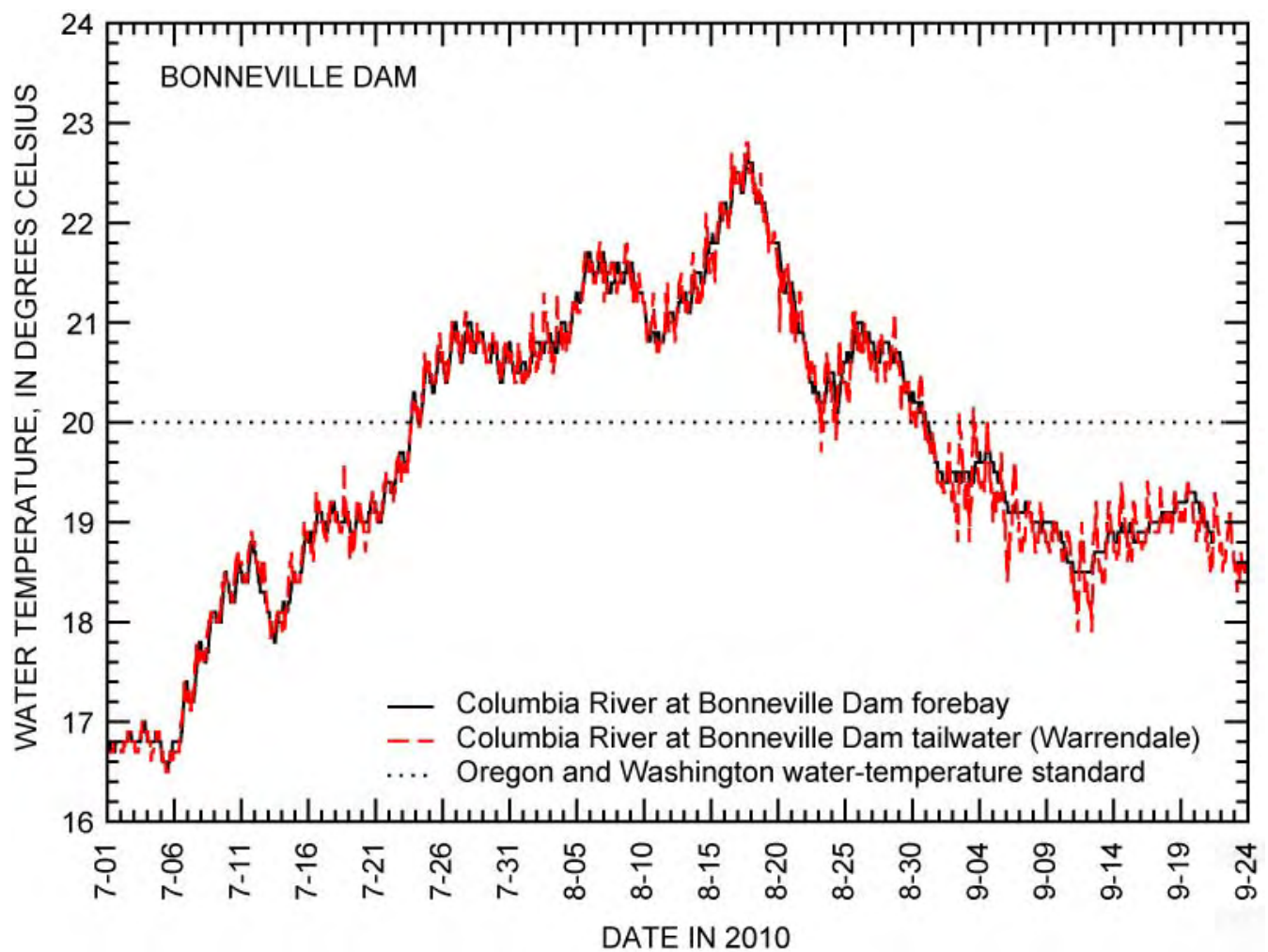

Figure 22. Graph showing water temperature upstream of Bonneville Dam and downstream of Bonneville Dam at Warrendale, lower Columbia River, Oregon and Washington, summer 2010.

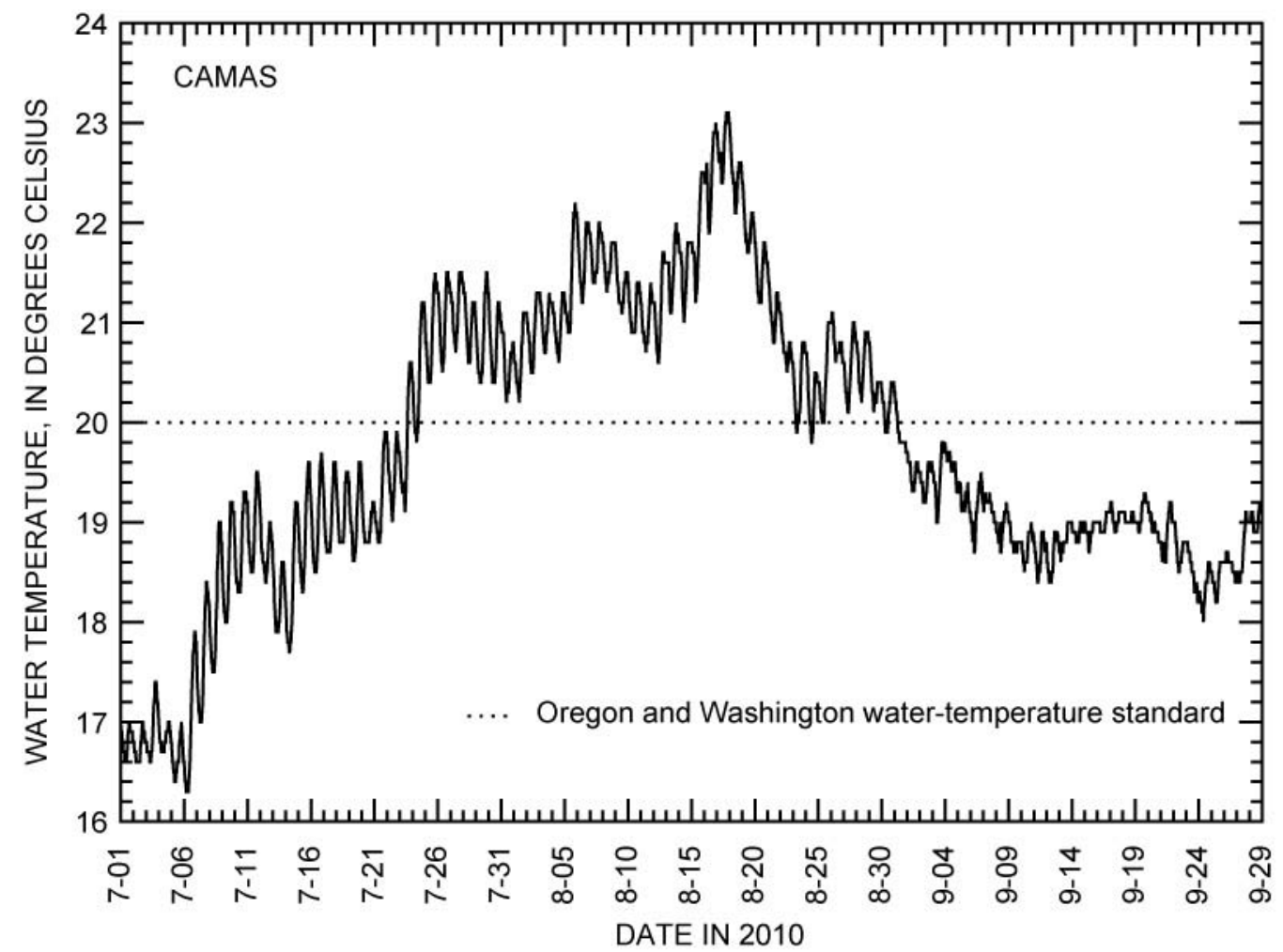

Figure 23. Graph showing water temperature downstream of Bonneville Dam at Camas, lower Columbia River, Oregon and Washington, summer 2010. 


\section{Acknowledgments}

The authors acknowledge the aid and funding support of the U.S. Army Corps of Engineers. Our special thanks go to James L. Britton (USACE) for technical and logistical support of the project. The authors also thank Amy M. Brooks (USGS) for preparing summaries and analyses of data. 


\section{References Cited}

Colt, J., 1984, Computation of dissolved gas concentrations in water as functions of temperature, salinity, and pressure: American Fisheries Society Special Publication 14, 154 p.

Jones, J.C., Tracey, D.C., and Sorensen, F.W., eds., 1991, Operating manual for the U.S. Geological Survey's data-collection system with the Geostationary Operational Environmental Satellite: U.S. Geological Survey Open-File Report 91-99, 237 p. (Available at http://pubs.er.usgs.gov/usgspubs/ofr/ ofr9199.)

State of Oregon, 2009, Order approving the U.S. Army Corps of Engineer's request for a waiver to the State's total dissolved gas water quality standard: Oregon Department of Environmental Quality, 4 p., accessed October 25, 2010, at http://www.deq.state.or.us/WQ/TMDLs/docs/columbiariver/tdg/ USACEWaiiver2010.pdf

State of Oregon, 2008, Water quality standards-Beneficial uses, policies, and criteria for Oregon: Oregon Department of Environmental Quality, accessed October 25, 2010, at http://arcweb.sos.state.or.us/rules/OARs_300/OAR_340/340_041.html

State of Washington, 2006a, Fresh water designated uses and criteria-Aquatic life total dissolved gas (TDG) criteria, WAC 173-201A-200(1)(f), accessed October 25, 2010, at http://apps.leg.wa.gov/WAC/default.aspx?cite $=173-201 \mathrm{~A}-200$

State of Washington, 2006b, Water quality standards for surface waters of the State of Washington, 103 p., accessed October 25, 2010, at http://www.ecy.wa.gov/pubs/wac173201a.pdf

Tanner, D.Q., and Bragg, H.M., 2001, Quality-assurance data, comparison to water-quality standards, and site considerations for total dissolved gas and water temperature, lower Columbia River, Oregon and Washington, 2001: U.S. Geological Survey Water-Resources Investigations Report 2001-4273, 14 p. (Available at http://pubs.er.usgs.gov/usgspubs/wri/wri014273.)

Tanner, D.Q., Bragg, H.M., and Johnston, M.W., 2003, Total dissolved gas and water temperature in the Lower Columbia River, Oregon and Washington, 2003-Quality-assurance data and comparison to water-quality standards: U.S. Geological Survey Water-Resources Investigations Report 2003-4306, 24 p. (Available at http://pubs.er.usgs.gov/usgspubs/wri/wri034306.)

Tanner, D.Q., Bragg, H.M., and Johnston, M.W., 2004, Total dissolved gas and water temperature in the Lower Columbia River, Oregon and Washington, 2004-Quality-assurance data and comparison to water-quality standards: U.S. Geological Survey Scientific Investigations Report 2004-5249, 27 p. (Available at http://pubs.er.usgs.gov/usgspubs/sir/sir20045249.)

Tanner, D.Q., Bragg, H.M., and Johnston, M.W., 2005, Total dissolved gas and water temperature in the Lower Columbia River, Oregon and Washington, 2005-Quality-assurance data and comparison to water-quality standards: U.S. Geological Survey Data Series 148, 31 p. (Available at http://pubs.er.usgs.gov/usgspubs/ds/ds148.)

Tanner, D.Q., Bragg, H.M., and Johnston, M.W., 2006, Total dissolved gas and water temperature in the Lower Columbia River, Oregon and Washington, 2006-Quality-assurance data and comparison to water-quality standards: U.S. Geological Survey Data Series 235, 24 p. (Available at http://pubs.er.usgs.gov/usgspubs/ds/ds235.)

Tanner, D.Q., Bragg, H.M., and Johnston, M.W., 2007, Total dissolved gas and water temperature in the Lower Columbia River, Oregon and Washington, 2007-Quality-assurance data and comparison to water-quality standards: U.S. Geological Survey Open-File Report 2007-1408, 23 p. (Available at http://pubs.er.usgs.gov/usgspubs/ofr/ofr20071408.) 
Tanner, D.Q., Bragg, H.M., and Johnston, M.W., 2008, Total dissolved gas and water temperature in the Lower Columbia River, Oregon and Washington, 2008-Quality-assurance data and comparison to water-quality standards: U.S. Geological Survey Open-File Report 2008-1357, 25 p. (Available at http://pubs.er.usgs.gov/usgspubs/ofr/ofr20081357.)

Tanner, D.Q., Bragg, H.M., and Johnston, M.W., 2009, Total dissolved gas and water temperature in the Lower Columbia River, Oregon and Washington, 2009-Quality-assurance data and comparison to water-quality standards: U.S. Geological Survey Open-File Report 2009-1288, 26 p. (Available at http://pubs.er.usgs.gov/usgspubs/ofr/ofr20081288.)

Tanner, D.Q., Harrison, H.E., and McKenzie, S.W., 1996, Total dissolved gas, barometric pressure, and water temperature data, lower Columbia River, Oregon and Washington, 1996: U.S. Geological Survey Open-File Report 96-662A, 85 p. (Available at http://pubs.er.usgs.gov/usgspubs/ofr/ofr96662A.)

Tanner, D.Q. and Johnston, M.W., 2001, Data-collection methods, quality-assurance data, and site considerations for total dissolved gas monitoring, lower Columbia River, Oregon and Washington, 2000: U.S. Geological Survey Water-Resources Investigations Report 2001-4005, 19 p. (Available at http://pubs.er.usgs.gov/usgspubs/wri/wri014005.)

Tanner, D.Q., Johnston, M.W., and Bragg, H.M., 2002, Total dissolved gas and water temperature in the Lower Columbia River, Oregon and Washington, 2002-Quality-assurance data and comparison to water-quality standards: U.S. Geological Survey Water-Resources Investigations Report 2002-4283, 12 p. (Available at http://pubs.er.usgs.gov/usgspubs/wri/wri024283.)

U.S. Environmental Protection Agency, 1986, Quality criteria for water 1986: U.S. Environmental Protection Agency Publication No. 440-5-86-001, accessed November 19, 2010, at http://nepis.epa.gov/EPA/html/Pubs/pubtitleOAR.htm. 
